\title{
Somatodendritic Depolarization-Activated Potassium Currents in Rat Neostriatal Cholinergic Interneurons Are Predominantly of the A Type and Attributable to Coexpression of Kv4.2 and Kv4.1 Subunits
}

\author{
W.-J. Song, T. Tkatch, G. Baranauskas, N. Ichinohe, S. T. Kitai, and D. J. Surmeier \\ Department of Anatomy and Neurobiology, College of Medicine, University of Tennessee, Memphis, Memphis, \\ Tennessee 38163
}

Unlike other neostriatal neurons, cholinergic interneurons exhibit spontaneous, low-frequency, repetitive firing. To gain an understanding of the $\mathrm{K}^{+}$channels regulating this behavior, acutely isolated adult rat cholinergic interneurons were studied using whole-cell voltage-clamp and single-cell reverse transcription-PCR techniques. Cholinergic interneurons were identified by the presence of choline acetyltransferase (ChAT) mRNA. Depolarization-activated potassium currents in cholinergic interneurons were dominated by a rapidly inactivating, $\mathrm{K}^{+}$-selective A current that became active at subthreshold potentials. Depolarizing prepulses inactivated this component of the current, leaving a delayed, rectifier-like current. Micromolar concentrations of $\mathrm{Cd}^{2+}$ dramatically shifted the voltage dependence of the A current without significantly affecting the delayed rectifier. The A-channel antagonist 4-aminopyridine (4-AP) produced a voltage-dependent block $\left(\mathrm{IC}_{50}, \sim 1 \mathrm{~mm}\right)$ with a prominent crossover at millimolar concentrations. On the other hand, TEA preferentially blocked the sustained current component at concentrations $<10 \mathrm{~mm}$. Single-cell mRNA pro- filing of subunits known to give rise to rapidly inactivating $\mathrm{K}^{+}$ currents revealed the coexpression of Kv4.1, Kv4.2, and Kv1.4 mRNAs but low or undetectable levels of Kv4.3 and Kv3.4 mRNAs. Kv1.1, $\beta 1$, and $\beta 2$ subunit mRNAs, but not $\beta 3$, were also commonly detected. The inactivation recovery kinetics of the A-type current were found to match those of Kv4.2 and 4.1 channels and not those of Kv1.4 or Kv1.1 and $\beta 1$ channels. Immunocytochemical analysis confirmed the presence of Kv4.2 but not Kv1.4 subunits in the somatodendritic membrane of ChAT-immunoreactive neurons. These results argue that the depolarization-activated somatodendritic $\mathrm{K}^{+}$currents in cholinergic interneurons are dominated by Kv4.2- and Kv4.1containing channels. The properties of these channels are consistent with their playing a prominent role in governing the slow, repetitive discharge of interneurons seen in vivo.

Key words: A current; delayed rectifier; tetraethylammonium; 4-aminopyridine; voltage clamp; single-cell RT-PCR; acutely dissociated neurons; Kv1; Kv2; Kv3
Although cholinergic interneurons account for only a few percent of all neostriatal neurons (Kemp and Powell, 1971; Phelps et al., 1985), they exert a profound influence on striatal circuitry. For example, it has long been known that disruption of the cholinergic regulation of medium spiny neurons through muscarinic receptors ameliorates movement disorders accompanying striatal dopamine depletion (Hornykiewcz, 1973). More recently it has been suggested that cholinergic interneurons are instrumental in the acquisition of procedural or associative learning tasks (Aosaki et al., 1994; Graybiel et al., 1994).

Despite their functional importance, cholinergic interneurons have been difficult to study because of their rarity. The first clear

Received Sept. 15, 1997; revised Feb. 9, 1998; accepted Feb. 10, 1998

This work was supported by National Institute of Neurological Diseases and Stroke, United States Public Health Service Grants NS-34696 to D.J.S. and NS26473 to D.J.S. and S.T.K. and a Parkinson's Disease Foundation fellowship to W.J.S. We thank Dr. J. Flores-Hernandez for assisting in some of the physiological experiments, Dr. B. Teng for help in the immunocytochemical experiments, and Dr. L. Dudkin for her technical help. We also thank Dr. James Trimmer for providing Kv4.2C antisera.

W.-J.S., T.T., and G.B. contributed equally to this work.

Correspondence should be addressed to Dr. D. J. Surmeier, Department of Anatomy and Neurobiology, University of Tennessee, 855 Monroe Avenue, Memphis, TN 38163.

Dr. Song's present address: Department of Biophysical Engineering, Faculty of Engineering Science, Osaka University, Toyonaka 560, Japan.

Copyright (C) 1998 Society for Neuroscience $\quad 0270-6474 / 98 / 183124-14 \$ 05.00 / 0$ glimpse of interneuronal physiology suggested that they had relatively depolarized resting potentials and distinctive spike patterns (Wilson et al., 1990). These studies were extended by Kawaguchi $(1992,1993)$ in showing that striatal choline acetyltransferase (ChAT)-immunoreactive neurons in slices exhibited a prolonged spike afterhyperpolarization with slow ramp-like voltage trajectories preceding the next spike, enabling these cells to discharge at very low rates.

Slow ramp-like voltage trajectories of this sort often are governed by inactivating, A-type $\mathrm{K}^{+}$currents (Connor and Stevens, 1971a,b; Rogawski, 1985). However, since their original description, physiological studies have revealed that A-type currents exhibit a wide range of biophysical and pharmacological properties, sometimes specializing them for other cellular functions (Rogawski, 1985; Rudy, 1988). This functional heterogeneity is reflected in the molecular heterogeneity of A-like $\mathrm{K}^{+}$channels. Depolarization-activated $\mathrm{K}^{+}$channels are thought to be formed by four $\alpha$ subunits drawn from four $\alpha$ subunit gene families (Kv1-4) (Stuhmer et al., 1989; Pongs, 1993). Expression studies have shown that homomeric channels arising from Kv1.4, Kv3.4, and Kv4.1, Kv4.2, and Kv4.3 subunits give rise to A-type channels (Stuhmer et al., 1989; Baldwin et al., 1991; Schroter et al., 1991; Serodio et al., 1994, 1996). In addition, inactivating, A-like channels can be formed when ancillary $\beta 1$ subunits are coexpressed 
with subunits of the Kv1 family that normally have delayed rectifier properties (Rettig et al., 1994; Heinemann et al., 1996; Sewing et al., 1996). Based on studies in heterologous cell types, several of these channels (e.g., Kv4.2) have biophysical properties that would enable them to significantly slow the rate of membrane depolarization at subthreshold potentials and to promote lowfrequency repetitive discharge. However, it is unclear to what extent these subunits are expressed in cholinergic interneurons and, if so, to what extent they are found within the somatodendritic membrane.

Based on these previous studies, it was our working hypothesis that the capacity of cholinergic interneurons to discharge at low rates was attributable to the expression of A-type $\mathrm{K}^{+}$channels with features similar to those formed from Kv4.2 subunits. To test this hypothesis, whole-cell $\mathrm{K}^{+}$currents in identified cholinergic interneurons were studied using voltage-clamp techniques. The molecular identity of the channel subunits underlying the currents was determined by single-cell reverse transcription-PCR (RTPCR) analysis (Monyer and Lambolez, 1995; Surmeier et al., 1996; Yan and Surmeier, 1996; Yan et al., 1997) and immunohistochemistry (Sheng et al., 1992; Maletic-Savatic et al., 1995). The results described below argue that striatal cholinergic interneurons coexpress several of the $\alpha$ and $\beta$ subunits known to produce A-type channels but, within the somatodendritic membrane, Kv4.2 and Kv4.1 channels are the predominate channel types and possess the biophysical properties necessary to regulate repetitive discharge.

\section{MATERIALS AND METHODS}

Acute dissociation procedure. Striatal neurons from young adult ( $>4 \mathrm{wk})$ male rats were acutely dissociated using procedures similar to those we described previously (Surmeier et al., 1995; Song and Surmeier, 1996). In brief, rats were anesthetized with methoxyflurane and decapitated; brains were quickly removed, iced, and then blocked for slicing. The blocked tissue was cut in $400 \mu \mathrm{m}$ slices with a Microslicer (Dosaka, Kyoto, Japan) while bathed in a high-sucrose solution (in mM: 250 sucrose, $2.5 \mathrm{KCl}, 1 \mathrm{Na}_{2} \mathrm{HPO}_{4}, 2 \mathrm{MgSO}_{4}, 2 \mathrm{CaCl}_{2}, 11$ glucose, and 15 HEPES, pH 7.4; 300-305 mOsm/1). Slices were then incubated for 1-6 hr at room temperature $\left(20-22^{\circ} \mathrm{C}\right)$ in $\mathrm{NaHCO}_{3}$ buffered saline bubbled with $95 \% \mathrm{O}_{2}$ and $5 \% \mathrm{CO}_{2}$ (in mM: $126 \mathrm{NaCl}, 2.5 \mathrm{KCl}, 2 \mathrm{CaCl}_{2}, 2 \mathrm{MgCl}_{2}$, $26 \mathrm{NaHCO}_{3}, 1.25 \mathrm{NaH}_{2} \mathrm{PO}_{4}, 1$ pyruvic acid, 0.2 ascorbic acid, 0.1 $\mathrm{N}^{\omega}$-nitro-L-arginine, 1 kynurenic acid, and 10 glucose, $\mathrm{pH} 7.4$ with $\mathrm{NaOH} ; 300-305$ mOsm/1). All reagents were obtained from Sigma (St. Louis, MO). Slices were then removed into low- $\mathrm{Ca}^{2+}$, HEPES-buffered saline (in mM: $140 \mathrm{Na}$-isethionate, $2 \mathrm{KCl}, 4 \mathrm{MgCl}_{2}, 0.1 \mathrm{CaCl}_{2}, 23$ glucose, and 15 HEPES, pH 7.4; 300-305 mOsm/l), and with the aid of a dissecting microscope, regions of the dorsal striatum were dissected and placed in an oxygenated Cell-Stir chamber (Wheaton, Inc., Millville, NJ) containing Pronase $(1-2 \mathrm{mg} / \mathrm{ml})$ in HEPES-buffered HBSS (Sigma) at $35^{\circ} \mathrm{C}$. Dissections were limited to tissue rostral to the anterior commissure to reduce the possibility of contamination from globus pallidus. After 30-40 min of enzyme digestion, tissue was rinsed three times in the low- $\mathrm{Ca}^{2+}$, HEPES-buffered saline and mechanically dissociated with a graded series of fire-polished Pasteur pipettes. The cell suspension was then plated into a $35 \mathrm{~mm}$ Lux Petri dish mounted on the stage of an inverted microscope containing HEPES-buffered HBSS. After allowing the cells to settle, the solution bathing the cells was changed to a HEPES-buffered saline.

Whole-cell recordings. Whole-cell recordings used standard techniques (Hamill et al., 1981; Song and Surmeier, 1996). Electrodes were pulled from Corning (Corning, NY) 7052 glass and fire-polished before use. The internal solution consisted of (in mM): $60 \mathrm{~K}_{2} \mathrm{SO}_{4}, 60 \mathrm{~N}$-methyl-Dglucamine, $4 \mathrm{MgCl}_{2}$, $40 \mathrm{HEPES}, 2.5-5$ EGTA or 5 BAPTA, 12 phosphocreatine, $2 \mathrm{Na}_{2} \mathrm{ATP}, 0.2 \mathrm{Na}_{3} \mathrm{GTP}$, and 0.1 leupeptin, pH 7.2 with $\mathrm{H}_{2} \mathrm{SO}_{4}$ (osmolarity, 265-275 mOsm/l). The $\mathrm{pH}$ of $N$-methylglucamine solutions was measured with a Corning model 476570 probe. The external solution consisted of (in $\mathrm{mm}$ ): $140 \mathrm{Na}$-isethionate, 2-5 KCl, 2-4 $\mathrm{MgCl}_{2}, 0-2 \mathrm{Ca}^{2+}, 10$ HEPES, 12 glucose, and 0.001 TTX, pH 7.4 with $1 \mathrm{~N} \mathrm{NaOH}(\sim 2 \mathrm{ml})$ (osmolarity, $300 \pm 5 \mathrm{mOsm} / \mathrm{l})$.
In all the experiments, $\mathrm{Na}^{+}$currents were blocked by TTX. $\mathrm{Ca}^{2+}$ currents were eliminated in one of two ways. In almost all of the experiments described below, $\mathrm{Ca}^{2+}$ in the bathing medium was replaced on an equimolar basis by $\mathrm{Mg}^{2+}$. This eliminated measurable currents that were sensitive to inorganic $\mathrm{Ca}^{2+}$ channel blockers. In some experiments, $\mathrm{CdCl}_{2}(200-400 \mu \mathrm{M})$ was added to the external solution to block $\mathrm{Ca}^{2+}$ currents. These experiments are explicitly described below.

In some experiments, 4-AP (Sigma) or tetraethylammonium chloride (TEA) (Sigma) was applied. When 4-AP was included in the extracellular solutions, the $\mathrm{pH}$ was adjusted to 7.4 using $\mathrm{H}_{2} \mathrm{SO}_{4}$. When 4-AP or TEA was applied at concentrations $>1 \mathrm{~mm}$, the osmolarity was adjusted by reducing the concentration of Na-isethionate.

Solutions were applied with a gravity-fed sewer pipe system. An array of application capillaries ( $\sim 400 \mu \mathrm{m}$ inner diameter) was positioned a few hundred micrometers from the cell under study. Solution changes were effected by altering the position of the array with a DC drive system controlled by a microprocessor-based controller (Newport-Klinger, Inc., Irvine, CA). Solution changes were complete within $<1 \mathrm{sec}$.

Recordings were obtained with an Axon Instruments 200 patch-clamp amplifier and controlled and monitored with a PC 486 clone running pClamp software (version 6.0) with a $125 \mathrm{kHz}$ interface (Axon Instruments Inc., Foster City, CA). Electrode resistances were typically 2-6 $\mathrm{M} \Omega$ in the bath. After seal rupture, series resistance (7-15 $\mathrm{M} \Omega$ ) was compensated $(80-90 \%)$ and periodically monitored. Potentials were not corrected for the liquid junction potential, which was estimated to be 1 $\mathrm{mV}$, except when calculating the permeability to $\mathrm{K}^{+}$relative to $\mathrm{Na}^{+}$ Recordings were made only from large-sized neurons $(>14 \mathrm{pF})$ that had only a few short $(<75 \mu \mathrm{m})$ proximal dendrites.

Statistical methods. Statistical analyses (including nonlinear curve fitting) were performed with Systat (Evanston, IL; version 5.2). Sample statistics are given either as means with SD or as medians. Box plots were used for graphic presentation of the data because of the small sample sizes (Tukey, 1977). The box plot represents the distribution as a box with the median as a central line and the hinges as the edges of the box (the hinges divide the upper and lower halves of the distributions in half). The inner fences (shown as a line originating from the edges of the box) run to the limits of the distribution excluding outliers (defined as points that are $>1.5 \times$ the interquartile range beyond the interquartiles; Tukey, 1977); outliers are shown as asterisks or circles.

Boltzmann functions were fit to normalized conductance or current plots using previously described formulas (Bargas et al., 1994) with a least squares fitting routine.

Single-neuron RT-PCR analysis. As we have reported previously (Song and Surmeier, 1996; Surmeier et al., 1996; Yan and Surmeier, 1996), after recording, cells were lifted up into a stream of control solution and aspirated into the electrode by applying negative pressure. Electrodes contained $\sim 5 \mu \mathrm{l}$ of sterile recording solution (see above). Some cells were harvested without recording, with electrodes filled with water. The capillary glass used for making electrodes had been heated to $200^{\circ} \mathrm{C}$ for $4 \mathrm{hr}$. Sterile gloves were worn during the procedure to minimize RNase contamination.

After aspiration, the electrode was broken, and contents were ejected into a presiliconized, $0.5 \mathrm{ml}$ Eppendorf tube containing $5 \mu \mathrm{l}$ diethylpyrocarbonate-treated water, $0.5 \mu \mathrm{l}$ of RNasin $(28,000 \mathrm{U} / \mathrm{ml})$, and $0.5 \mu \mathrm{l}$ of dithiothreitol (DTT) $(0.1 \mathrm{M})$. One microliter of either oligo-dT $(0.5 \mu \mathrm{g} / \mu \mathrm{l})$ or random hexanucleotides $(50 \mathrm{ng} / \mu \mathrm{l})$ was added and mixed before the mixture was heated at $70^{\circ} \mathrm{C}$ for $10 \mathrm{~min}$ and incubated on ice for $>1$ min. Single-strand cDNA was synthesized from the cellular mRNA by adding SuperScript II reverse transcriptase $(1 \mu \mathrm{l}, 200 \mathrm{U} / \mu \mathrm{l})$, $10 \times$ PCR buffer $(2 \mu \mathrm{l}, 200 \mathrm{~mm}$ Tris $\mathrm{Cl}, \mathrm{pH} 8.4$, and $500 \mathrm{~mm} \mathrm{KCl}), \mathrm{MgCl}_{2}$ ( $2 \mu \mathrm{l}, 25 \mathrm{~mm})$, RNasin $(0.5 \mu \mathrm{l}, 28,000 \mathrm{U} / \mathrm{ml})$, DTT $(1.5 \mu \mathrm{l}, 0.1 \mathrm{M})$, and mixed dNTPs $(1 \mu \mathrm{l}, 10 \mathrm{~mm})$. The reaction mixture $(20 \mu \mathrm{l})$ was incubated at $42^{\circ} \mathrm{C}$ for $50 \mathrm{~min}$. The reaction was terminated by heating the mixture to $70^{\circ} \mathrm{C}$ for $15 \mathrm{~min}$ and then icing. The RNA strand in the RNA-DNA hybrid was then removed by adding $1 \mu \mathrm{l}$ of RNase $\mathrm{H}(2 \mathrm{U} / \mu \mathrm{l})$ and incubating for $20 \mathrm{~min}$ at $37^{\circ} \mathrm{C}$. All reagents except RNasin (Promega, Madison, WI) were obtained from Life Technologies (Grand Island, NY). The cDNA from the reverse transcriptase of RNA in single striatal neurons was subjected to PCR to detect the expression of mRNAs coding for $\mathrm{K}^{+}$channels, ChAT, and the neuropeptides enkephalin and substance $\mathrm{P}$.

Conventional PCR was performed with a thermal cycler (MJ Research, Inc., Watertown, MA). Thin-walled plastic tubes (Perkin-Elmer, Norwalk, CT) were used. PCR primers were developed from GenBank sequences with commercially available Oligo software (National Bio- 


\begin{tabular}{|c|c|c|c|c|}
\hline mRNA & Primer position & Sequence & Product length (bases) & Accession number \\
\hline \multirow[t]{2}{*}{$\mathrm{Kv} \beta 1$} & 1275 & AAGGGAGAAAACAGCAAAACAAGC & 168 & X70662 \\
\hline & 1419 & TGGCACCAAGGTTTTCAATGAGTT & & \\
\hline \multirow[t]{2}{*}{$\mathrm{Kv} \beta 2$} & 628 & ACTCTCCCTGCGGCAGACAG & 204 & X76724 \\
\hline & 808 & CCATTGTCATAGGCCAAGGTCATT & & \\
\hline \multirow[t]{2}{*}{$\mathrm{Kv} \beta 3$} & 468 & TCCTGGAGGCGGTAATGGAG & 536 & X76723 \\
\hline & 984 & GACTGCTGGGGTCTGAACGA & & \\
\hline \multirow[t]{2}{*}{ Kv1.1 } & 1360 & CCGCCGCAGCTCCTCTACTATCA & 209 & M26161 \\
\hline & 1545 & CAAGGGTTTTGTTTGGGGGCTTTT & & \\
\hline \multirow[t]{2}{*}{ Kv1.2 } & 1816 & CCGGGAGACAGAGGGAGAGG & 538 & X16003 \\
\hline & 2330 & TTGATATGGTGTGGGGGCTATGA & & \\
\hline \multirow[t]{2}{*}{ Kv1.4 } & 2310 & CTGGGGGACAAGTCAGAGTATCTA & 434 & X16002 \\
\hline & 2725 & ACTCTCCTCGGGACCACCT & & \\
\hline \multirow[t]{2}{*}{ Kv1.5 } & 2415 & TTTGCAAGACTGGGGGTTCC & 251 & M27158 \\
\hline & 2642 & GTGGGCTTAAATACTCGGTGGTGT & & \\
\hline \multirow[t]{2}{*}{ Kv3.4 } & 2131 & TCAGGCACACGGGACAGAAAC & 522 & X62841 \\
\hline & 2630 & GGGCAGAGGACTTGGGAGACATA & & \\
\hline \multirow[t]{2}{*}{ Kv4.1 } & 1386 & CGGACAAATGCTGTGCGTTAG & 467 & M64226 \\
\hline & 1829 & TAGGGGAGGAAGGTTGACTTTCAT & & \\
\hline \multirow[t]{2}{*}{ Kv4.2 } & 2165 & CCGAATCCCAAATGCCAATGTG & 265 & S64320 \\
\hline & 2406 & CCTGACGATGTTTCCTCCCGAATA & & \\
\hline \multirow[t]{2}{*}{ Kv4.3 } & 1389 & GCAAGCGCAATGGACTCCTCAA & 217 & U42975 \\
\hline & 1582 & GAAGGGCTTCTGGTGGATGGGTAG & & \\
\hline
\end{tabular}

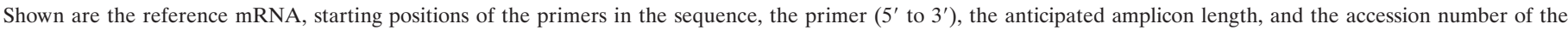
GenBank sequence used to construct the primer.

sciences, Plymouth, MN). The primers used in this study are shown in Table 1. Positive controls for primer efficiency were run using wholebrain cDNA. Primers for ChAT, enkephalin, and substance P mRNA were described previously (Surmeier et al., 1996; Yan and Surmeier, 1996). To detect individual mRNAs, $2.5 \mu \mathrm{l}$ of the single-cell cDNA was used as a template for conventional PCR amplification. Reaction mixtures contained 2-2.5 $\mathrm{mM} \mathrm{MgCl}_{2}$, a $0.5 \mathrm{~mm}$ concentration of each of the dNTPs, $1 \mu \mathrm{M}$ primers, $2.5 \mathrm{U}$ of Taq DNA polymerase, and buffer (Promega). The thermal cycling program was $94^{\circ} \mathrm{C}$ for $1 \mathrm{~min}, 58^{\circ} \mathrm{C}$ (or $56^{\circ} \mathrm{C}$ for some primers) for $1 \mathrm{~min}$, and $72^{\circ} \mathrm{C}$ for $1.5 \mathrm{~min}$ for 45 cycles.

To identify mRNAs coexpressed in single neurons, a two-step protocol was used. In the first round, $2.5 \mu \mathrm{l}$ of the single-cell cDNA was used as a template in a multiplex (three or four pairs of primers) PCR reaction. The reaction mixture contained the same concentration of reagents as with conventional PCR, except for slightly decreased primer concentration $(0.5 \mu \mathrm{M})$. Fifteen cycles were performed. Then, an aliquot $(1 / 10)$ of this PCR product was used as a template for a second round ( 35 cycles) of PCR amplification with each pair of specific primers $(1 \mu \mathrm{M})$.

PCR products were separated by electrophoresis in $1.5-2 \%$ agarose gels and visualized by staining with ethidium bromide. In representative cases, amplicons were purified from the gel (QIAquick gel extraction kit; Qiagen, Hilden, Germany) and sequenced with a dye termination procedure by the University of Tennessee Molecular Resource Center or St. Jude Children's Research Hospital Molecular Resource Center. These sequences were found to closely match published sequences.

PCR reactions were performed following procedures designed to minimize the chances of cross-contamination (Cimino et al., 1990). Negative controls for contamination from extraneous and genomic DNA were run for every batch of neurons. To ensure that genomic DNA did not contribute to the PCR products, neurons were aspirated and processed in the normal manner, except that the reverse transcriptase was omitted. Contamination from extraneous sources was checked by replacing the cellular template with water. Both controls were consistently negative in these experiments.

Immunohistochemistry. Animals were anesthetized with sodium pentobarbital $(40 \mathrm{mg} / \mathrm{kg})$ and chloral hydrate $(170 \mathrm{mg} / \mathrm{kg})$ and were perfused through the ascending aorta with $100 \mathrm{ml}$ of $0.9 \%$ sodium chloride followed by $250 \mathrm{ml}$ of $4 \%$ paraformaldehyde in $0.1 \mathrm{M}$ phosphate buffer (PB), $\mathrm{pH}$ 7.4. Brains were removed, cut sagittally at the midline, postfixed $1 \mathrm{hr}$ in the same fixative, and then immersed overnight in $30 \%$
sucrose/PB. The brain was rapidly frozen by immersing in 2-methylbutane cooled by dry ice. The brain was sectioned at $15 \mu \mathrm{m}$ using a cryostat. Sections containing the striatum and the globus pallidus were mounted on glass slides.

For single-label immunohistochemistry, sections were incubated with $8 \%$ bovine serum albumin (BSA) in PBS, $\mathrm{pH} \mathrm{7.4,} \mathrm{for} 1 \mathrm{hr}$ at room temperature, and then, with the primary antibody diluted in PBS containing $1 \%$ BSA (PBSB), were incubated overnight at $4^{\circ} \mathrm{C}$. These primary antibodies included mouse monoclonal anti-rat Kv1.4 antibody (Upstate Biotechnology, Lake Placid, NY) at a dilution of 1:100 and rabbit affinity-purified polyclonal anti-Kv4.2C antibody (provided by Dr. James S. Trimmer, State University of New York, Stony Brook, NY) at a dilution of 1:500. This antibody recognizes Kv4.2 subunits and at least one form of Kv4.3 subunit. After three washes in PBS, Kv1.4 sections were incubated with PBSB containing biotinylated horse anti-mouse IgG antibody (1:200; Vector Laboratories, Burlingame, CA), and Kv4.2C sections were incubated with PBSB containing biotinylated goat antirabbit $\mathrm{IgG}$ antibody (1:200; Vector Laboratories) for $3 \mathrm{hr}$ at room temperature. All the sections were washed again in PBS and then incubated for $2 \mathrm{hr}$ at room temperature with 1:100 avidin-biotin-horseradish peroxidase complex (ABC Vectastain kit; Vector Laboratories) in PBS. After an additional wash in PBS, sections were incubated in $50 \mathrm{~mm}$ Tris buffer, $\mathrm{pH} 7.6$, containing $0.02 \%$ diaminobenzidine, $0.3 \%$ nickel ammonium sulfate, and $0.002 \% \mathrm{H}_{2} \mathrm{O}_{2}$ for 5-15 min. After washing in Tris buffer, sections were dehydrated and coverslipped.

For double-label immunofluorescence, sections were first incubated with $8 \%$ BSA in PBS for $1 \mathrm{hr}$ at room temperature and then with a mixture of 1:50 rabbit affinity-purified polyclonal anti-Kv4.2C antibody and 1:250 monoclonal mouse anti-ChAT antibody (Chemicon, Temicula, $\mathrm{CA}$ ) in PBSB overnight at $4^{\circ} \mathrm{C}$. After washing three times in PBS, sections were incubated with PBSB containing biotinylated goat antirabbit IgG antibody (1:200; Vector Laboratories) and fluorescein isothiocyanate (FITC)-conjugated horse anti-mouse IgG antibody (1:150; Vector Laboratories) for $3 \mathrm{hr}$ at room temperature, were washed again in PBS, and then were incubated for $2 \mathrm{hr}$ with 1:500 avidin-D-Texas Red (Vector Laboratories) in PBS. After additional washes in PBS, sections were coverslipped with 1,4-diazabicyclo-[2.2.2]octane in phosphatebuffered glycerol. They were examined under an Olympus epifluorescence microscope with an appropriate filter for FITC or Texas Red.

Controls for nonspecific staining for primary antiserum or cross- 
Figure 1. Depolarization-activated $\mathrm{K}^{+}$currents in neostriatal cholinergic interneurons are dominated by an A current. $A$, Whole-cell $\mathrm{K}^{+}$currents recorded from a cholinergic interneuron. $\mathrm{Na}^{+}$and $\mathrm{Ca}^{2+}$ currents have been eliminated (see Materials and Methods). Inset, Photomicrograph of an acutely isolated cholinergic interneuron and a medium-sized neuron. Scale bar, $25 \mu \mathrm{m}$. B, Photomicrograph of an ethidium bromide-stained gel in which PCR amplicons from the cell recorded from in $A$ were separated by electrophoresis. Note the presence of ChAT amplicon but not enkephalin $(E n k)$ and substance $\mathrm{P}(S P)$ amplicons. $C$, Whole-cell recording from a medium spiny neuron showing currents that inactivate more slowly than in $A$. $D$, Photomicrograph of an ethidium bromide-stained gel in which PCR amplicons from the cell recorded from in $C$ were separated by electrophoresis. Note the absence of ChAT amplicon and the presence of enkephalin but not substance P amplicons.
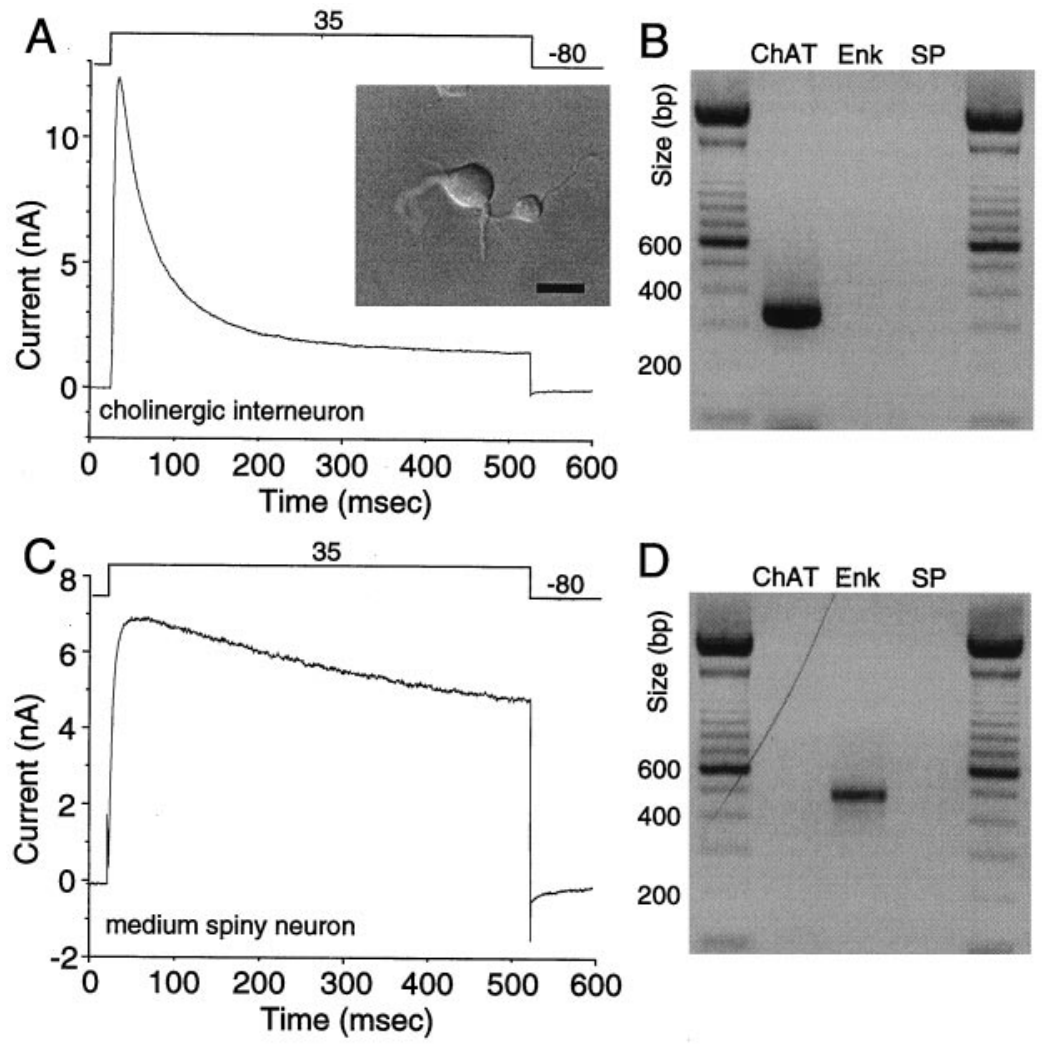

reactivity of antiserums were performed. For single-labeled immunohistochemistry, the control sections were incubated in the absence of the primary antibody in the first step. For double-labeled immunofluorescence, the control sections were incubated with PBSB containing either antibodies for $\mathrm{Kv} 4.2 \mathrm{C}$ or ChAT or with PBSB without any antibodies. These control sections were processed through each remaining step of the protocol in the same manner as the experimental sections. These control experiments indicated that there was no nonspecific labeling of neural soma or processes.

\section{RESULTS}

After dissociation, neurons with large cell bodies were easily recognized (Fig. 1A, inset). One to five of these large neurons were found per slice. Their whole-cell capacitance ranged from 14 to $22 \mathrm{pF}$ in our sample of 88 neurons. In agreement with previous studies (Yan and Surmeier, 1996; Yan et al., 1997), all large cells tested with single-cell RT-PCR techniques had detectable levels of choline acetyltransferase mRNA $(n=13)$ (Fig. $1 B)$. These large neurons did not express enkephalin or substance P mRNA, which are known to be found in striatal medium spiny neurons (Fig. 1B,D) (Graybiel, 1990). These results suggest that most, if not all, of the neurons used in this study were cholinergic interneurons.

\section{Depolarization-activated outward currents in cholinergic interneurons are dominated by a transient A-type current}

With $\mathrm{Na}^{+}$and $\mathrm{Ca}^{2+}$ currents eliminated, depolarizing voltage steps from hyperpolarized membrane potentials evoked outward currents in cholinergic interneurons. The currents were dominated by a large transient component (Fig. 1A). This current profile was significantly different from that seen in recordings from medium spiny neurons (Fig. 1C,D) (Nisenbaum et al., 1996). In cholinergic interneurons, peak current amplitude was $6.25 \pm$ 1.72 (mean $\pm \mathrm{SD} ; n=8$ ) times that at the end of a 500 msec test pulse to $+35 \mathrm{mV}$. This ratio was only $1.51 \pm 0.16(n=5)$ in the medium spiny cells. An analysis of tail currents evoked by a short depolarizing step $(50 \mathrm{msec})$ in $5 \mathrm{~mm}$ extracellular $\left[\mathrm{K}^{+}\right]$suggested that the evoked currents in interneurons were $\mathrm{K}^{+}$-selective, having a $\mathrm{p}_{\mathrm{K}} / \mathrm{p}_{\mathrm{Na}}$ ratio of $35: 1$ based on the Goldman-Hodgkin-Katz equation (Hille, 1992) (data not shown).

A-type currents were isolated by taking advantage of their sensitivity to holding potential (Connor and Stevens, 1971a; Neher, 1971). From hyperpolarized membrane potentials, depolarizing voltage steps evoked both rapidly and slowly inactivating currents (Fig. 2A). From more positive holding potentials (approximately -50$)$, depolarizing steps evoked only slowly inactivating currents (Fig. 2B). Subtraction of the currents evoked at depolarized potentials from those evoked from more hyperpolarized potentials isolated a rapidly inactivating, A-type current (Fig. 2C). The inset is a graph showing the currents on a faster time scale. A plot of the mean normalized peak chord conductances as a function of membrane voltage for a sample of neurons is shown in Figure $2 D$. These data were well fit with a Boltzmann function, having a half-activation voltage of $-27.2 \mathrm{mV}$ and a slope factor of $14.7 \mathrm{mV}$.

The steady-state voltage dependence of inactivation was studied by applying conditioning steps $(1.4 \mathrm{sec})$ to membrane potentials between -120 and $-30 \mathrm{mV}$ before a test step to $0 \mathrm{mV}$. As shown in Figure $3 A$, depolarizing steps diminished the transient currents evoked by the test step. A plot of mean normalized peak current amplitude as a function of conditioning voltage for a sample of neurons is shown in Figure $3 B$. These data were well fit with a single Boltzmann function having a half-inactivation voltage of $-93.5 \mathrm{mV}$ and a slope factor of $7.5 \mathrm{mV}$ (Fig. $3 B$ ). Also shown is the Boltzmann fit of the activation data (Fig. 2D), illustrating the complementary voltage dependence of the two 


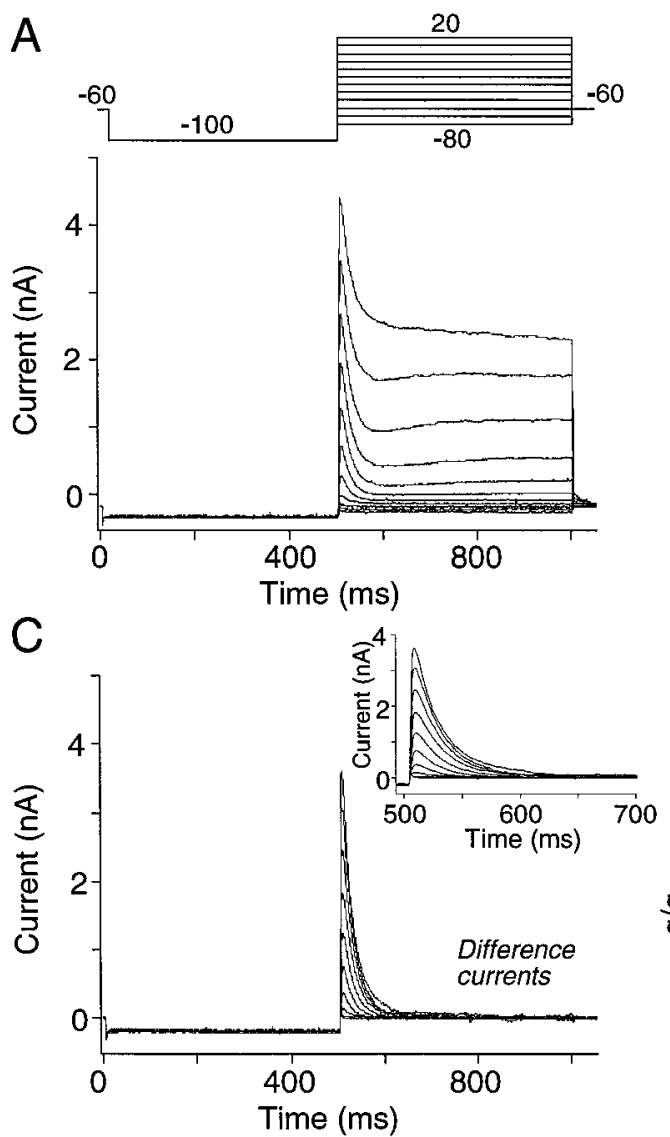

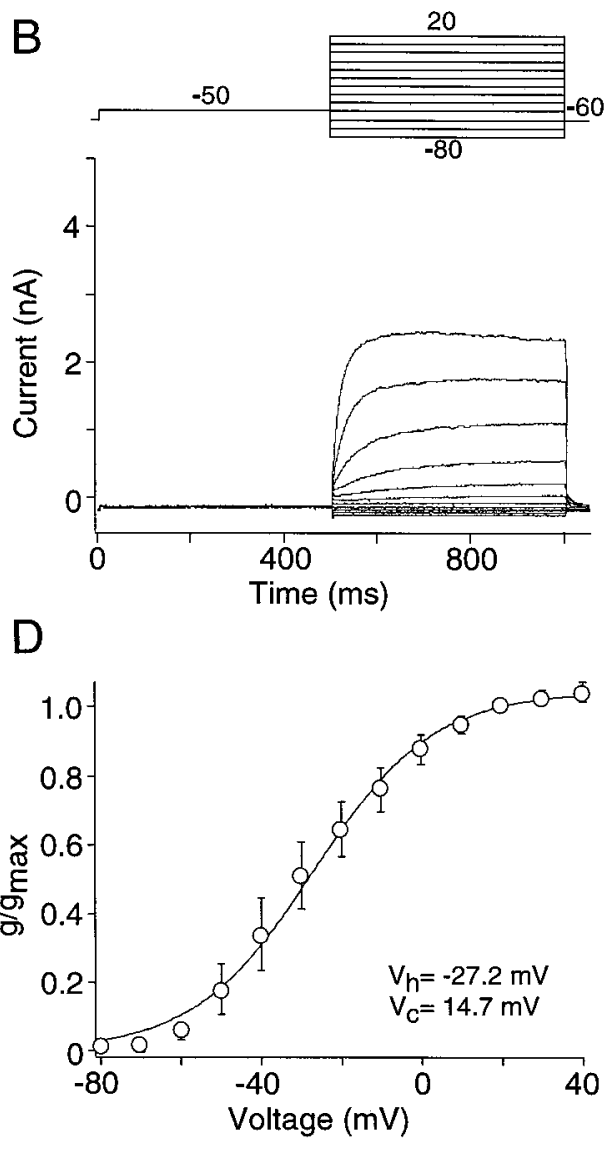

Figure 2. Interneurons express rapidly inactivating A-type currents that activate at subthreshold potentials. $A$, Currents evoked by a series of depolarizing steps from -80 to $+40 \mathrm{mV}$ after a hyperpolarizing step to $-100 \mathrm{mV}$. $B$, Currents evoked by the same set of depolarizing steps when preceded by a prepulse to $-50 \mathrm{mV}$. $C$, Difference currents obtained by subtracting $B$ from $A$. Inset, Same currents on a slightly faster time scale. $D$, Plot of mean normalized peak chord conductance as a function of step voltage for difference currents in a sample of four interneurons. Solid line, Boltzmann function with a half-activation voltage of $-27.2 \mathrm{mV}$ and a slope factor of $14.7 \mathrm{mV}$. processes. It can also be seen that there is a small window current for this conductance near the expected resting membrane potential (approximately $-65 \mathrm{mV}$ ) (Wilson et al., 1990).

Although many of the channels formed from cloned A-type subunits have similar activation and inactivation voltage dependence, the rates at which these channels inactivate or recover from inactivation are frequently quite different (Pongs, 1993; Deal et al., 1996). Inactivation kinetics are also crucial to the functional role played by A-type currents (Rogawski, 1985; Huguenard and McCormick, 1992). As a consequence, the development and recovery of A-type inactivation were characterized. The development of inactivation at depolarized membrane potentials was studied in two complementary ways. First, the inactivating phase of A-type currents (isolated by a subtraction protocol; Fig. 2) was fit with a decaying exponential function (Fig. $4 A$ ). At potentials above $-40 \mathrm{mV}$, currents were well fit with a single exponential, having a time constant of 20-25 msec. A plot of mean inactivation time constants as a function of test voltage is shown in Figure $4 B$. As has been described previously for certain classes of A-type current, the development of inactivation slowed modestly with increasing voltage. A potential complication of these experiments is that the subtraction procedure may not have completely isolated the A-type current. An alternative strategy that takes advantage of the rapid activation kinetics of the A-type current is to use a two-step protocol in which the duration of the conditioning prepulse is systematically varied (Fig. 4C). Current amplitudes were measured at times expected of the peak A current based on the initial test step. A plot of current amplitude as a function of prepulse duration was consistently well fit, with a single decreasing exponential having a time constant very close to that obtained by fitting the decay of currents during a single test step (Fig. 4D). The inset is a box plot summary of the inactivation time constants obtained from a sample of neurons.

The recovery from inactivation was studied by first inactivating A-type channels by holding at $-40 \mathrm{mV}$ and then stepping to hyperpolarized membrane potentials for increasing durations before a test step (Fig. $4 E$ ). Plots of peak current as a function of prepulse duration were well fit only with a sum of exponential functions (Fig. $4 F$ ). In our sample of interneurons, the smaller recovery time constant was between 10 and $20 \mathrm{msec}$, whereas the slower component of recovery was typically between 200 and 400 msec (Fig. 4F, inset).

\section{$\mathrm{Cd}^{2+}$ dramatically shifts the voltage dependence and kinetics of the A-type current}

In all of the experiments described in Figures $2-4, \mathrm{~K}^{+}$currents were isolated by blocking $\mathrm{Na}^{+}$currents with tetrodotoxin and eliminating $\mathrm{Ca}^{2+}$ currents by removing extracellular $\mathrm{Ca}^{2+}$ and replacing it with $\mathrm{Mg}^{2+}$. However, removing extracellular $\mathrm{Ca}^{2+}$ typically shortened the duration of recordings. Another commonly used strategy to eliminate $\mathrm{Ca}^{2+}$ currents that does not shorten recording times is to block $\mathrm{Ca}^{2+}$ channels with $\mathrm{Cd}^{2+}$ $(200-400 \mu \mathrm{M})$. Although the addition of $\mathrm{Cd}^{2+}$ to the extracellular solution effectively blocked $\mathrm{Ca}^{2+}$ channel currents, it had dramatic effects on the voltage dependence and kinetics of the transient $\mathrm{K}^{+}$currents.

A-type currents isolated in $\mathrm{Cd}^{2+}$-containing external solutions are shown in Figure $5 \mathrm{~A}$. A plot of average peak chord conductance for a sample of interneurons studied in this way is shown in Figure $5 B$. The data were well fit with a single Boltzmann func- 


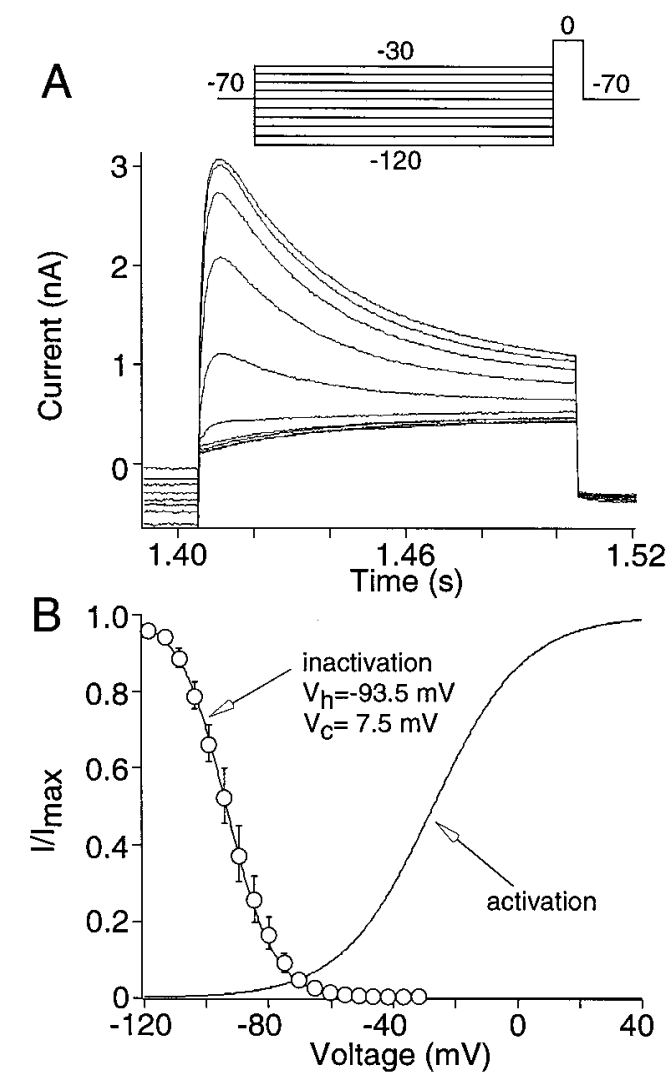

Figure 3. The A-type current in interneurons inactivated over a relatively negative voltage range. $A, \mathrm{~K}^{+}$currents evoked by a depolarizing step to $0 \mathrm{mV}$ after conditioning prepulses $(1.4 \mathrm{sec})$ to membrane potentials between -120 and $-30 \mathrm{mV}$. $B$, Plot of normalized peak current as a function of conditioning voltage for a sample of five neurons. Open circles, Mean values; error bars indicate SEM. Solid line, Boltzmann function with a half-inactivation voltage of $-93.5 \mathrm{mV}$ and a slope factor of $7.5 \mathrm{mV}$. Also plotted is the activation curve fitted to the data in Figure 2.

tion, having a half-activation voltage of $5.5 \mathrm{mV}$ and a slope factor of $11.6 \mathrm{mV}$. This is $32 \mathrm{mV}$ more positive than the fit obtained from data obtained in the absence of $\mathrm{Cd}^{2+}$ (Fig. 2B). The fit of the control data are plotted for the purpose of comparison. The voltage dependence of inactivation was shifted even more dramatically. Currents evoked by a two pulse protocol are shown in Figure $5 C$ (note that the abscissa before the test pulse is compressed). A plot of average normalized peak current as a function of prepulse voltage for our sample of interneurons was well fit with a single Boltzmann function, having a half-inactivation voltage of $-35.4 \mathrm{mV}$ and a slope factor of $5.2 \mathrm{mV}$. Also plotted is the fit of the data obtained in the absence of $\mathrm{Cd}^{2+}$ for comparison. The difference in the half-inactivation voltages was $57 \mathrm{mV}$.

In addition to shifting the voltage dependence of activation and inactivation, $\mathrm{Cd}^{2+}$ slowed the development of inactivation. At all of the voltages examined $(-30$ to $+40 \mathrm{mV})$, the inactivating phase of the current was well fit with a single exponential, having a time constant near $40 \mathrm{msec}$ (data not shown), considerably slower than in the absence of $\mathrm{Cd}^{2+}(\sim 20-25 \mathrm{msec})(n=5 ; p<$ 0.05 , Mann-Whitney $U$ test). The relative voltage independence of the time constants argues that the slowing in $\mathrm{Cd}^{2+}$ was not caused by the shift in the voltage dependence of inactivation. In contrast, the recovery of the A-type current from inactivation at $-100 \mathrm{mV}$ was not noticeably altered by $\mathrm{Cd}^{2+}$ (data not shown) ( $n=5 ; p>0.05$, Mann-Whitney $U$ test $)$.

\section{The A-type current was potently reduced by 4-aminopyridine but not tetraethylammonium}

One of the hallmarks of A-type currents is their sensitivity to 4-AP (Rogawski, 1985). In invertebrate neurons, 4-AP blocks A currents in a voltage- and time-dependent manner (Thompson, 1982). This aspect of the 4-AP block has been reported much less commonly in vertebrate neurons (Gustafsson et al., 1982; Surmeier et al., 1988; Huguenard et al., 1991; Stefani et al., 1992; Wu and Barish, 1992; Foehring and Surmeier, 1993; Nisenbaum et al., 1996). When applied to cholinergic interneurons, 4-AP reduced the peak current in a dose-dependent manner (Fig. $6 A$ ). The $\mathrm{IC}_{50}$ of 4-AP was near $1 \mathrm{~mm}$, assessed isochronally at the peak of the control current (Fig. 6B). In addition, 4-AP increased the amplitude of the current later in the pulse, creating a crossover of the current. This pattern of effects is typical of what has previously been described in invertebrate neurons and in heterologous expression systems transfected with Kv4.2 cRNA (Tseng et al., 1996). The current crossover after 4-AP application also suggests that there was little or no 4-AP-sensitive delayed rectifier current in these neurons.

In contrast, TEA preferentially blocked the sustained, delayed rectifier component of the current. As shown in Figure $7 A$, increasing concentrations of TEA reduced both peak and sustained current components. Difference current estimates of the TEA-sensitive currents revealed that at low millimolar concentrations, only a persistent current was blocked (Fig. 7B). This is consistent with the well described ability of TEA to block delayed rectifier-type channels (Rudy, 1988). The $\mathrm{IC}_{50}$ of the TEA block of the persistent current was $\sim 11 \mathrm{~mm}$ (Fig. $7 C$ ). However, it should be noted that at TEA concentrations $>10 \mathrm{~mm}$ a portion of the inactivating current was also blocked, suggesting that the transient, A-type current in interneurons was not as insensitive to TEA as other types of inactivating $\mathrm{K}^{+}$channel (Stuhmer et al., 1989).

\section{Cholinergic interneurons coexpress $\mathrm{K}^{+}$subunits that form A-like channels}

To identify the channel subunits responsible for the A-like current seen in whole-cell recordings, single-cell RT-PCR experiments were performed. Five $\mathrm{K}^{+}$channel subunits are known to form homomeric channels that have A-like properties: Kv1.4, Kv3.4, Kv4.1, Kv4.2, and Kv4.3 (Stuhmer et al., 1989; Baldwin et al., 1991; Schroter et al., 1991; Serodio et al., 1994; Serodio et al., 1996). In addition, Kv1 family channels that normally yield delayed rectifier type currents inactivate rapidly in the presence of ancillary $\beta 1$ subunits (Rettig et al., 1994; Heinemann et al., 1996; Sewing et al., 1996). To generate as comprehensive a profile as possible of A-type subunit mRNA expression, individual cholinergic interneurons were simultaneously analyzed for the expression of Kv1.1, Kv1.2, Kv1.4, Kv1.5, Kv3.4, Kv4.1, Kv4.2, Kv4.3, and $\beta 1-3$ mRNAs.

These experiments revealed that several of the subunits capable of forming A-like channels were coexpressed in interneurons. A photograph of an ethidium bromide-stained gel in which PCR amplicons from an individual cell have been separated by electrophoresis is shown in Figure $8 A$. A summary of the expression patterns of individual neurons is shown in Figure $8 B$. The only transcript that was detected in every neuron profiled was Kv4.2. Other subunits known to form homomeric channels with A-like properties were detected in a subset of cells (Kv4.1 and Kv1.4, $\sim 60 \%$ of all cells; $n=32$ ) or not detected at all (Kv4.3 and Kv3.4; $n=32$ ). 

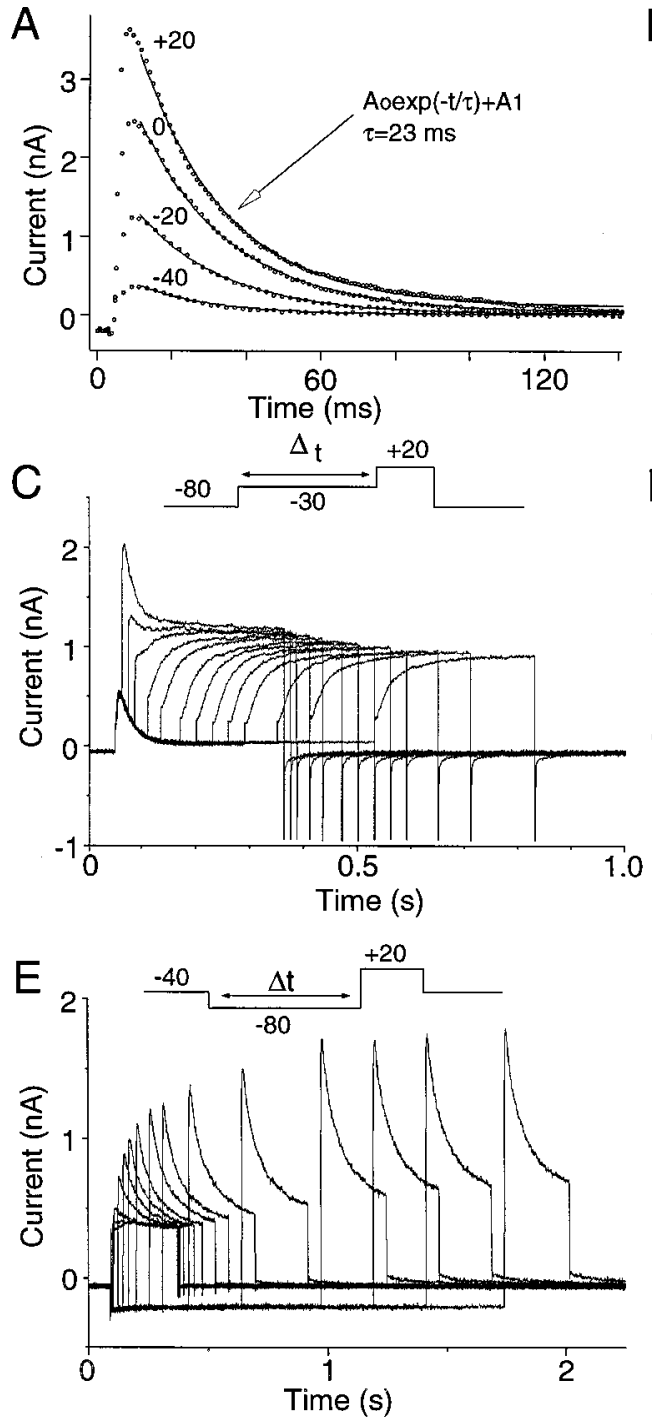
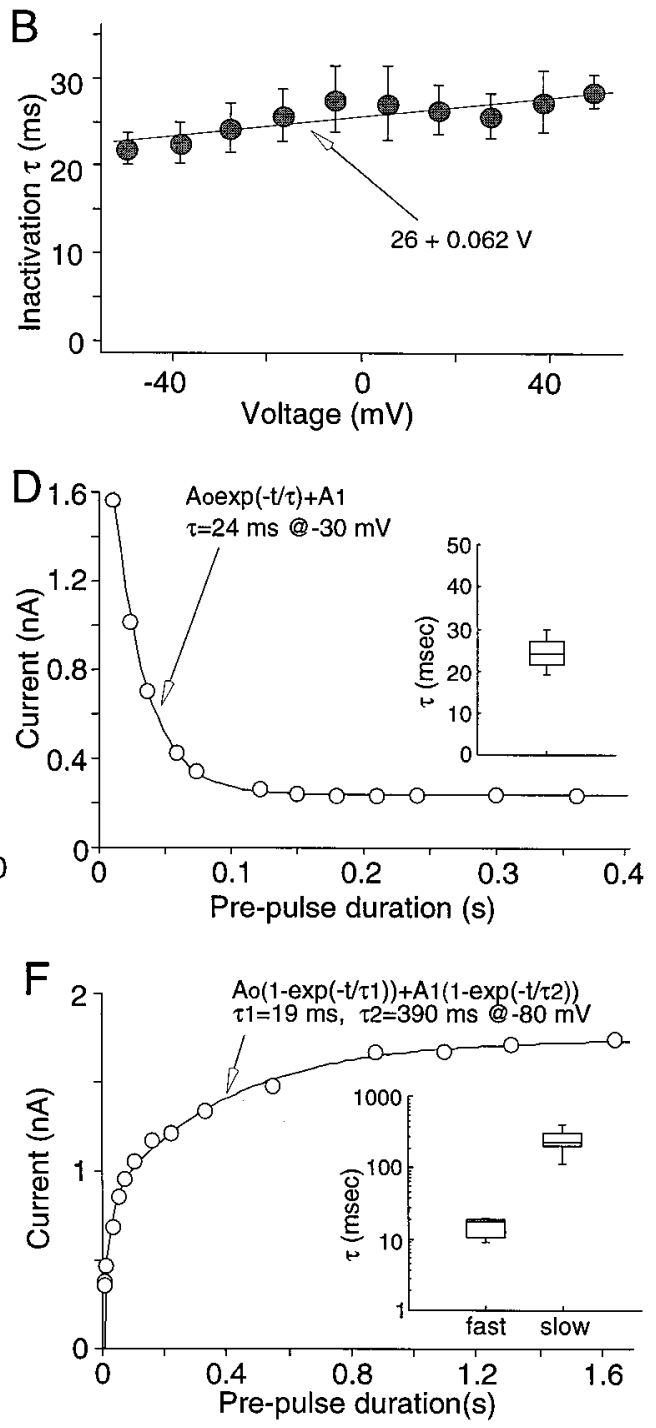

Figure 4. Interneuronal A-type currents inactivated and recovered from inactivation rapidly. $A$, A-type currents evoked by depolarizing steps from -40 to $20 \mathrm{mV}$ isolated by subtraction (Fig. 2). Inactivating phase at each voltage is fitted with a single exponential function with a time constant of $23 \mathrm{msec}$. $B$, Plot of mean \pm SEM inactivation time constant as a function of step voltage for a sample of six neurons. Data were fit with a straight line with an intercept of 26 $\mathrm{msec}$ and a slope of $0.062 \mathrm{msec} / \mathrm{mV}$. $C$, A-type currents were progressively inactivated by lengthening the duration of a step to $-30 \mathrm{mV}$ before a test step to 20 $\mathrm{mV}$. D, Plot of peak current measured isochronously as a function of prepulse duration. Data points were fitted with an exponential with a time constant of 24 msec (solid line). Inset, Box plot of time constants obtained in similar experiments for a sample of five neurons. $E$, Inactivation recovery was examined by inactivating A-type currents and then stepping to $-80 \mathrm{mV}$ for increasing periods before a test step to $20 \mathrm{mV}$. F, Plot of peak current as a function of prepulse duration (@-80 mV). Data were fit with a sum of exponentials (solid line) with time constants of 19 and 390 msec. Inset, Box plot summarizing the distribution of fast and slow time constants for a sample of eight neurons.
The mRNA for $\beta$ subunits was also commonly detected. $\beta 1$ and $\beta 2$ mRNAs were much more commonly detected than $\beta 3$ mRNA. The mRNAs for some of the Kv1 family subunits known to complex with $\beta 1$ subunits to yield A-like channels were also found in a subset of interneurons (Kv1.1, 50\%; Kv1.2, 20\%; Kv1.5, $0 \% ; n=27)$.

There are several potential reasons why a particular transcript might be detected in only a subset of neurons. One possibility is that the expression of that transcript varies across the interneuronal population, with some neurons expressing high levels and others expressing low or undetectable levels. Another possibility is that inefficiencies in the RT-PCR reaction are responsible. This could be attributable to inefficient reverse transcription resulting from protein and RNA binding to the transcripts or secondary structure of the transcript. It also could be attributable to inefficient PCR amplification.

Distinguishing between biological and technical possibilities is particularly important for the interpretation of the Kv1.4 mRNA profiles. Kv1.4 transcripts were the only detectable non-Kv4 family subunit mRNAs that could produce A-type $\mathrm{K}^{+}$channels with properties similar to those observed in interneurons. It was our working hypothesis that limitations in the RT-PCR reaction were responsible for the variation in Kv1.4 detection, not heterogeneity within the interneuronal population. To test this hypothesis, serial dilution experiments were performed. The rationale for these experiments is as follows. First, it is assumed that the RT-PCR efficiency for any one transcript is constant. Next, it is assumed that the fraction of the total cellular cDNA necessary to detect a particular transcript is inversely related to its abundance or amplification efficiency. This threshold fraction can be determined by performing the PCR reaction with serial dilutions of the original cellular cDNA. If there are two populations of neurons, one expressing a transcript at high levels and another expressing the same transcript at low levels, the distribution of thresholds across that population should be bimodal.

Serial dilution profiles for Kv4.2 and Kv1.4 mRNAs in two interneurons are shown in Figure $8 C$. A summary of these experiments is shown in Figure $8 D$. It is evident that the threshold densities for both Kv4.2 and Kv1.4 mRNAs were unimodal, suggesting that the interneuron population was homogeneous with regard to these two mRNAs.

\section{Somatodendritic A-type currents are attributable to channels with Kv4.2 and Kv4.1 subunits}

Based on the RT-PCR analysis, the somatodendritic A-type currents could have arisen from several different channel types. 
Figure 5. Extracellular $\mathrm{Cd}^{2+}$ dramatically shifted the voltage dependence of A-channel activation and inactivation gating. $A$, Difference currents evoked in the presence of $\mathrm{Cd}^{2+}(400 \mu \mathrm{M})$ by a series of depolarizing steps from -60 to $+60 \mathrm{mV}$ after a hyperpolarizing step to $-80 \mathrm{mV}$. $B$, Plot of mean normalized peak chord conductance \pm SEM as a function of step voltage for difference currents in a sample of six interneurons. Solid line, Boltzmann function with a half-activation voltage of $5.5 \mathrm{mV}$ and a slope factor of $11.6 \mathrm{mV}$. Also shown is the activation curve fitted to the data obtained in the absence of $\mathrm{Cd}^{2+} . C$, $\mathrm{K}^{+}$currents evoked by a depolarizing step to $0 \mathrm{mV}$ after conditioning prepulses to membrane potentials between -80 and $+10 \mathrm{mV}$. D, Plot of normalized peak current as a function of conditioning voltage for a sample of six neurons. Open circles, Mean values; error bars indicate SEM. Solid line, Boltzmann function with a halfinactivation voltage of $-36.4 \mathrm{mV}$ and a slope factor of $5.2 \mathrm{mV}$. Also plotted is the activation curve fitted to the data in Figure 3.
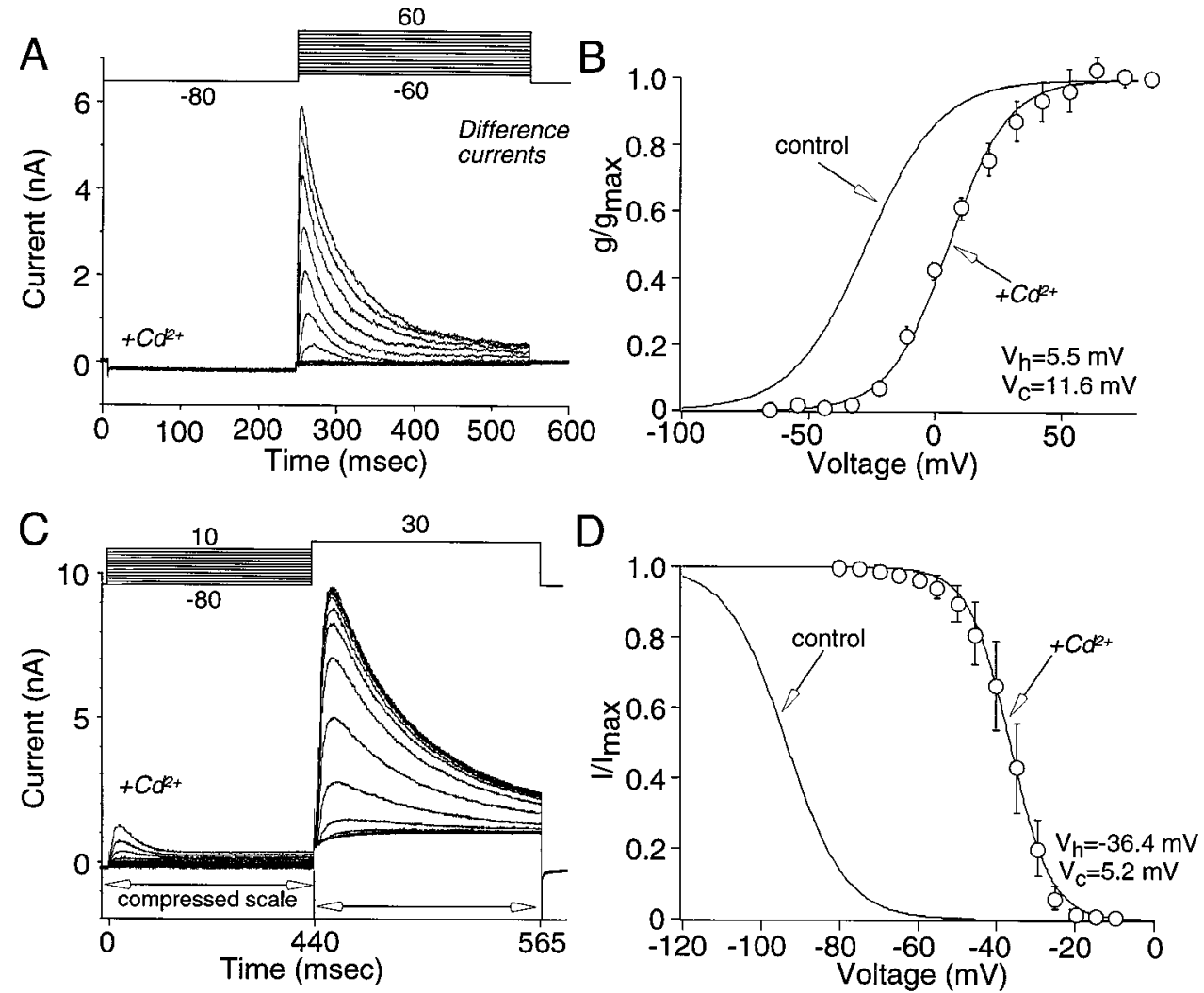

Despite the fact that their mRNA was present, Kv1.1 and $\beta 1$ subunit-containing channels are unlikely to have made a significant contribution to somatodendritic currents, because their 4-AP affinity is considerably higher than the channels responsible for the observed currents (Stuhmer et al., 1989; Rettig et al., 1994). Moreover, their inactivation rates are much faster than those seen in interneurons (Rettig et al., 1994). The potential contribution of Kv1.2 and $\beta 1$ channels can be discounted on the same grounds. However, Kv4 and Kv1.4 channels have more similar pharmacological sensitivities and inactivation kinetics (Stuhmer et al., 1989; Serodio et al., 1994). One biophysical feature that distinguishes these channel types in heterologous systems is recovery from inactivation (Bertoli et al., 1994, 1996; Serodio et al., 1994). Unlike Kv4 family channels, Kv1.4-containing channels have a slow component of inactivation recovery with a time constant of seconds. As shown in Figure 4, $E$ and $F$, a very slow component of inactivation recovery was not present (or very small) in this sample of neurons. To provide further confirmation of this result and the inference from the serial dilution experiments that the interneuron population was homogeneous, combined patchclamp and RT-PCR experiments were performed. In these experiments, the recovery kinetics of the A-type current were determined, and then the neuron was aspirated and profiled for ChAT, Kv4.2, and Kv1.4 mRNAs. A typical recovery record is shown in Figure $9 A$. Normalized plots of peak current as a function of recovery interval at $-95 \mathrm{mV}$ in cells having detectable levels of Kv1.4 (filled symbols; $n=4$ ) and those only having detectable levels of Kv4.2 (open symbols; $n=7$ ) are shown in Figure $9 B$. The inset is a scatter plot of the amplitudes of the fast and slow components of recovery for each group. There was no obvious relationship between the detection of Kv1.4 and the properties of inactivation recovery. In none of the cells examined

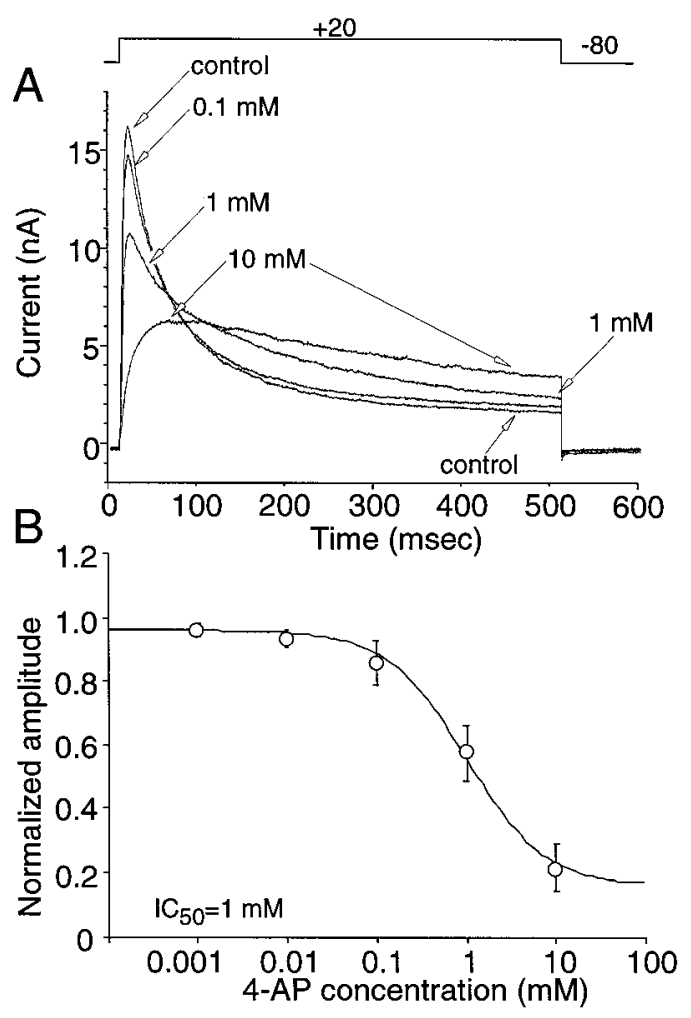

Figure 6. 4-AP blocked A-type currents in interneurons. $A, \mathrm{~K}^{+}$currents evoked by a step to $+20 \mathrm{mV}$ in the presence of increasing concentrations of 4-AP. Note the prominent crossover of currents at $>1 \mathrm{~mm}$ concentrations. $B$, Plot of average peak current \pm SEM (measured isochronously) as a function of 4-AP concentration for a sample of four neurons. The data were fit with a Langmuir isotherm with $1 \mathrm{mM} \mathrm{IC}_{50}$. 

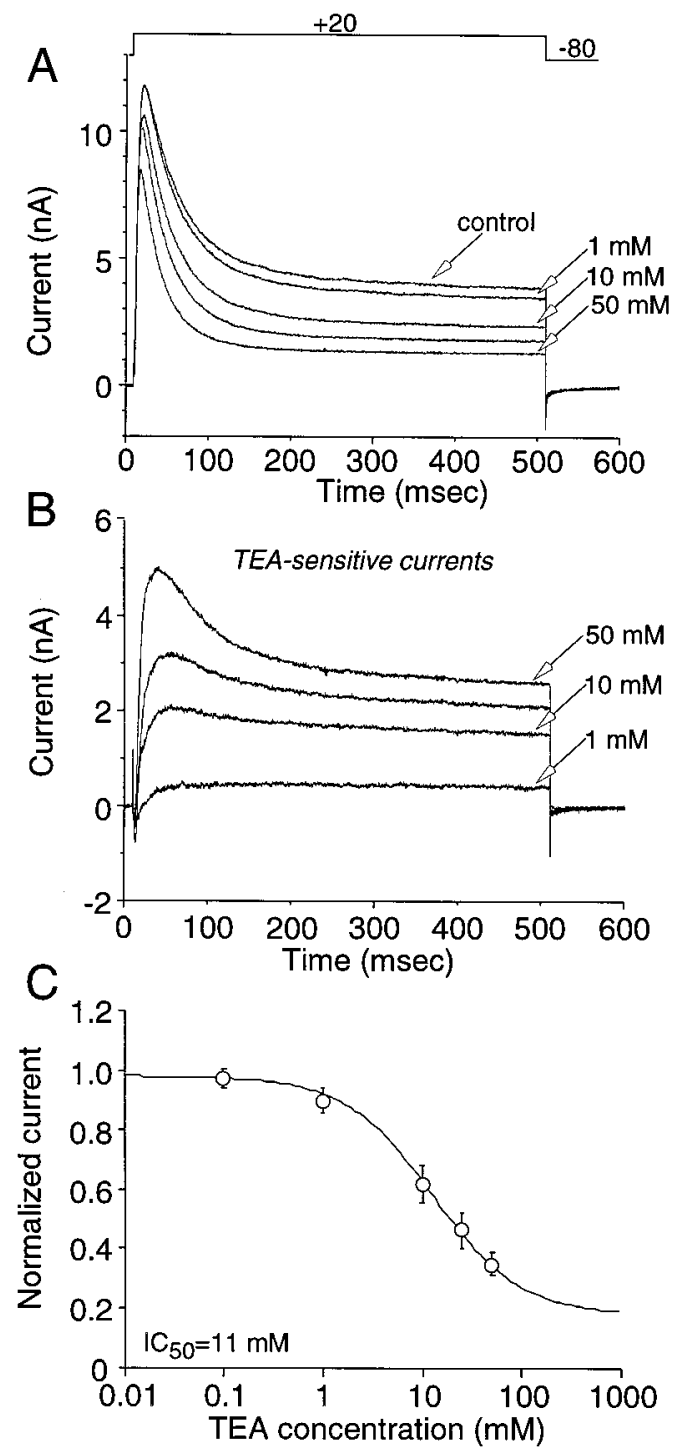

Figure 7. TEA preferentially blocked delayed rectifier currents. $A, \mathrm{~K}^{+}$ currents evoked by a step to $+20 \mathrm{mV}$ in the presence of increasing concentrations of TEA. $B$, TEA-sensitive currents isolated by subtraction from the control trace in $A$. Note that below $\sim 10 \mathrm{~mm}$ TEA, the transient component of the current is relatively unaffected. $C$, Plot of average current amplitude \pm SEM measured at the end of the voltage step as a function of TEA concentration for a sample of four neurons. The data were fit with a Langmuir isotherm with $11 \mathrm{~mm} \mathrm{IC}_{50}$.

was there a prominent component of recovery with a time constant of seconds.

To ensure that a slow component of recovery was not missed, an additional experiment was performed. First, the A-type current was inactivated by holding at $-60 \mathrm{mV}$. Then, the cell was stepped to $-95 \mathrm{mV}$ for either 1.5 or $25 \mathrm{sec}$ before the delivery of a test step to $-20 \mathrm{mV}$. As shown in Figure 9, $C$ and $D$, the currents evoked by the test step were very similar after holding at $-95 \mathrm{mV}$ for $1.5 \mathrm{sec}$ and for $25 \mathrm{sec}$, arguing against the presence of a significant slow component of inactivation recovery. This was true in neurons in which only Kv4.2 mRNA (Fig. 9C) was detected as well as in cells in which both Kv4.2 and Kv1.4 mRNA was found (Fig. 9D).

Although these results strongly implicate Kv4.2- and Kv4.1containing channels, they depend on the assumption that the properties of heterologously expressed channels are similar to those in native expression systems. To provide an additional test of our hypothesis, immunocytochemical studies were performed using a monoclonal Kv1.4 antibody and an affinity-purified polyclonal antibody that recognizes Kv4.2 and potentially Kv4.3 subunits. These experiments revealed that Kv1.4 subunits were localized primarily to fibers within the striatum and terminal fields within the globus pallidus (Fig. 10A). In contrast, Kv4.2 and Kv4.3 subunits were clearly present within the somata and dendrites of large striatal neurons (Fig. 10B, arrowheads); medium-sized neurons were also labeled but to a lesser extent. Double-label immunocytochemistry for Kv4.2 and Kv4.3 (Fig. 10C) and ChAT (Fig. $10 D$ ) consistently found this $\mathrm{K}^{+}$channel subunit in the dendrites and soma of cholinergic interneurons. Given the apparent absence of Kv4.3 mRNA in ChAT interneurons, the immunoreactivity in the somatodendritic membrane of these neurons can be attributed to Kv4.2 subunits.

\section{DISCUSSION}

\section{Interneuronal somatodendritic $\mathrm{K}^{+}$currents are largely attributable to A-type channels}

The results presented show that depolarization-activated, $\mathrm{Ca}^{2+}$. independent $\mathrm{K}^{+}$currents in the somatodendritic membrane of striatal interneurons are dominated by an A-type current. This conductance had many of the biophysical and pharmacological features of A-type conductances described previously in invertebrate (Connor and Stevens, 1971a; Neher, 1971; Hagiwara et al., 1981) and vertebrate cells (Rogawski, 1985; Rudy, 1988). In particular, the $\mathrm{K}^{+}$-selective conductance began to activate at subthreshold potentials, having a half-activation voltage near -27 $\mathrm{mV}$. On depolarization, the conductance inactivated monoexponentially with a time constant between $20-25 \mathrm{msec}$ at all potentials in which evoked currents could be accurately measured $(-40$ $\mathrm{mV}$ or greater). Steady-state inactivation developed at membrane potentials below the activation threshold and was accurately described by a Boltzmann function with a half-inactivation voltage near $-90 \mathrm{mV}$.

A notable feature of the A-type current in these neurons was its sensitivity to extracellular $\mathrm{Cd}^{2+}$. The addition of $20-400 \mu \mathrm{M}$ $\mathrm{Cd}^{2+}$ to the bath shifted the voltage dependence of activation by $32 \mathrm{mV}$, whereas the voltage dependence of inactivation was shifted even more $(57 \mathrm{mV})$. In addition, the kinetics of inactivation at depolarized potentials were slowed by extracellular $\mathrm{Cd}^{2+}$, decaying monoexponentially with a time constant of 40-50 msec rather than 20-25 msec. In contrast, the kinetics of recovery from inactivation were not altered. Qualitatively similar effects of $\mathrm{Cd}^{2+}$ on gating of A-type currents have been described previously (Mayer and Sugiyama, 1988; Agus et al., 1991; Andreasen and Hablitz, 1992; Klee et al., 1995), although the magnitude of the shifts in activation and inactivation were substantially larger in cholinergic interneurons.

\section{The properties of the A current are consistent with channels composed of Kv4.2 and Kv4.1 subunits}

Insights into the molecular architecture of the A-type channels in cholinergic interneurons is of clear value to understanding how these channels contribute to interneuron physiology and signaling. Molecular cloning and heterologous expression studies have shown that Kv1.4, Kv3.4, Kv4.1, Kv4.2, and Kv4.3 subunits are capable of forming homomeric channels that rapidly inactivate and are sensitive to 4-AP, the hallmarks of A-type channels (Stuhmer et al., 1989; Baldwin et al., 1991; Schroter et al., 1991; 
A

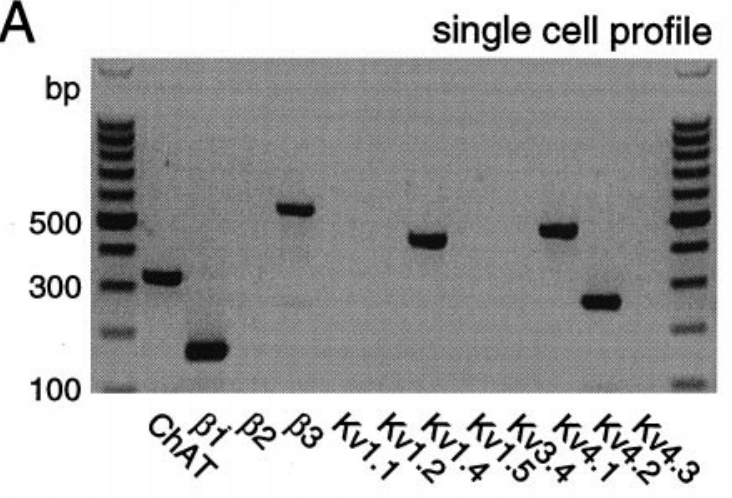

C Kv4.2 serial dilution

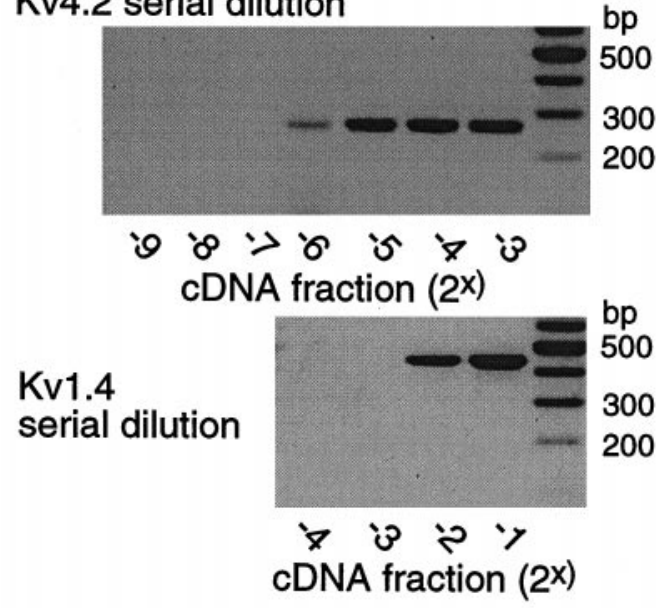

B

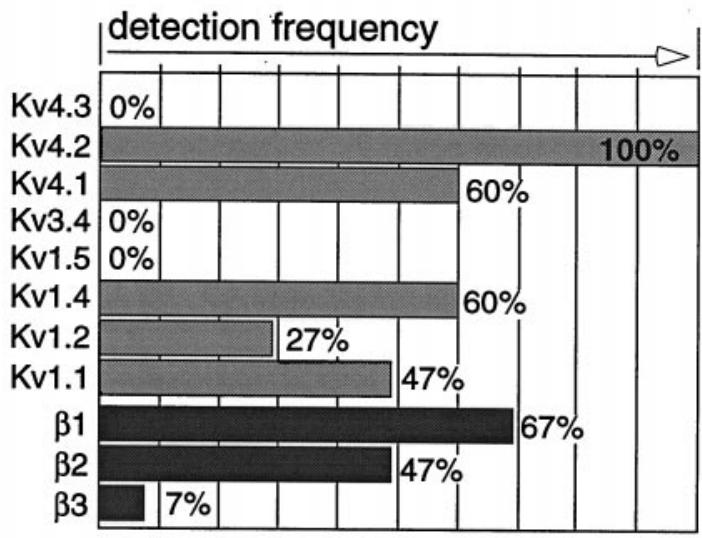

D

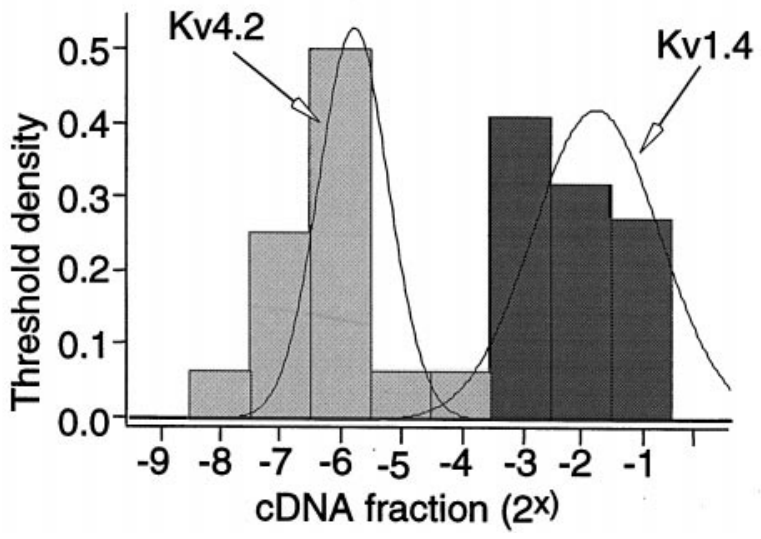

Figure 8. Interneurons express several $\alpha$ subunit mRNAs capable of producing A-type channels. $A$, Photomicrograph of an ethidium bromide-stained gel in which the PCR products from a single cholinergic interneuron have been separated by electrophoresis. This neuron had detectable levels of $\beta 1$, $\beta 3, \mathrm{Kv1.4}, \mathrm{Kv} 4.1$, and Kv4.2 mRNAs. Lanes at either end of the gel are size markers. $B$, Summary diagram of the expression profiles in 15 cholinergic interneurons. The percent of the sample in which a particular mRNA was detected is coded by the total length of the bar. $C$, $D$, The question of heterogeneity of Kv4.2 and Kv1.4 mRNA expression in ChAT interneurons was addressed by serially diluting the total cellular cDNA from the same cell for PCR. C, Photographs of two representative gels from two different cells show clear presence of Kv4.2 amplicons with $2^{-6}$ (1/64) or larger amounts of the total cellular cDNA, whereas only $2^{-2}(1 / 4)$ or more of the total cell cDNA was enough to see Kv1.4 amplicons clearly. $D$, Summary of the data from such experiments for Kv1.4 $(n=22)$ and $\operatorname{Kv} 4.2(n=15)$ mRNAs. The distribution of threshold dilutions for each mRNA is plotted as a normalized density. The smooth lines are Gaussian fits of the distributions. Note unimodal distribution for both mRNAs.

Serodio et al., 1994, 1996). In addition, $\beta 1$ subunits are capable of transforming delayed rectifier-like channels composed of Kv1 family subunits (Kv1.1, Kv1.2, and Kv1.5) into rapidly inactivating, A-like channels (Rettig et al., 1994; Heinemann et al., 1996; Sewing et al., 1996). To determine which of these subunits contributed to the channels underlying the $\mathrm{K}^{+}$currents seen in cholinergic interneurons, single-cell RT-PCR profiling was performed. These techniques have been used successfully in the past to identify a wide range of cellular mRNAs, including those coding for voltage-dependent $\mathrm{K}^{+}$channels (Gurantz et al., 1996; Baro et al., 1997). The latter study also used quantitative techniques to show a linear relationship between mRNA abundance and apparent channel abundance.

Our studies suggested that Kv1.5, Kv3.4, or Kv4.3 subunits are not expressed at significant levels in cholinergic interneurons, despite their ready detection in other cell types and in wholebrain cDNA (data not shown). However, these experiments did reveal the presence of Kv4.2, Kv4.1, Kv1.4, Kv1.1, Kv1.2, and $\beta 1$ mRNAs. With the exception of Kv4.2 mRNA, not all of these
mRNAs were found in every interneuron. Does this suggest that there are subsets of cholinergic interneuron with different complements of $\mathrm{K}^{+}$channels? The unimodal distribution of detection thresholds for Kv4.2 and Kv1.4 mRNAs argues against this interpretation. A more likely interpretation is that the failure to detect Kv1.4, Kv4.1, Kv1.1, and Kv1.2 mRNA in some neurons is a reflection of low mRNA abundance and/or inefficiencies in the RT-PCR procedure.

If we assume that all these subunit mRNAs are present in interneurons, do they all contribute to channels underlying the somatodendritic currents? Several observations strongly argue against this scenario. Because subunits from Kv1 and Kv4 gene families do not coassemble to form heteromeric channels (McCormack et al., 1990; Covarrubias et al., 1991), it is necessary only to consider the properties of channels with subunits derived from one or the other family. One of the hallmarks of channels composed of Kv1 family $\alpha$ subunits is the presence of a slow component of inactivation recovery with a time constant in the range of seconds, rather than milliseconds (Bertoli et al., 1994, 1996; 
A

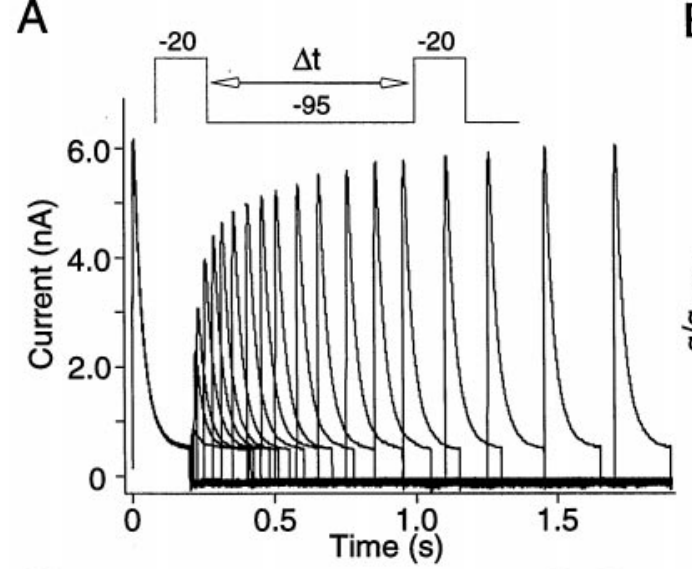

B

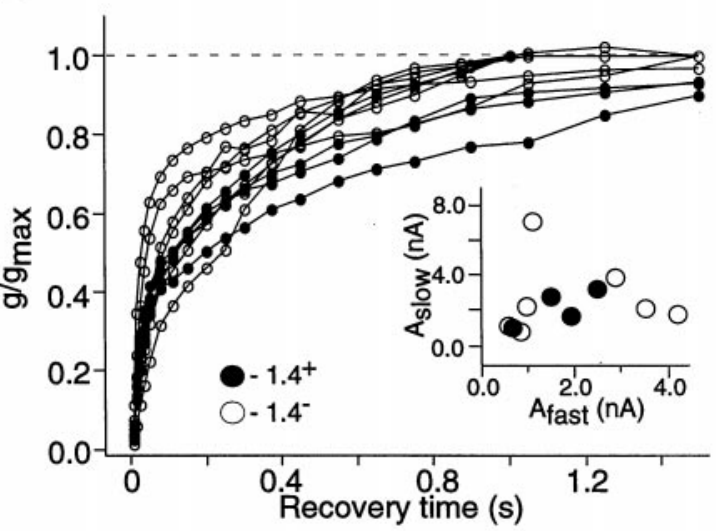

D
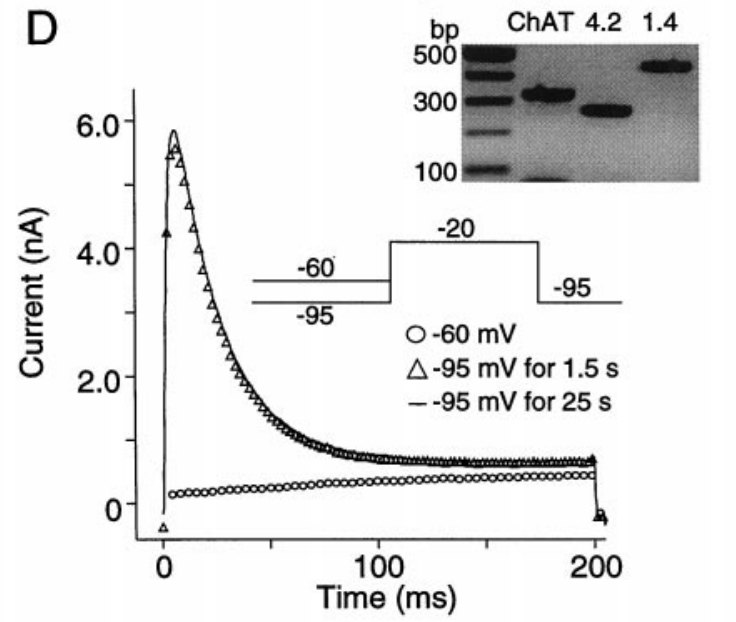

Figure 9. Inactivation recovery kinetics were not correlated with the detection of Kv1.4 mRNA. $A$, Inactivation recovery was examined by a double-pulse protocol. Current responses to two $200 \mathrm{msec}$ test pulses to $-20 \mathrm{msec}$ separated by increasing the intervals at $-95 \mathrm{mV}$ were recorded while holding the cell at $-95 \mathrm{mV}$. Note almost complete recovery after $1.5 \mathrm{sec}$ at $-95 \mathrm{mV}$. B. Plot of peak current as a function of interpulse duration. After recordings the cells were tested by RT-PCR for the presence of Kv4.2 and Kv1.4 mRNA. Kv4.2 mRNA was detected in all, whereas Kv1.4 mRNA was detected only in 4 of 10 cells. Note the almost complete overlap of the traces from the cells in which Kv1.4 mRNA was detected ( filled circles) and the cells in which Kv1.4 mRNA was not detected (open circles). Inset, No correlation is shown between the amplitude of slow or fast components of recovery from inactivation and the presence of Kv1.4 mRNA ( filled circles). $C, D$, The presence of a very slow ( $>1$ sec) recovery from inactivation was tested by comparison of current amplitude after $1.5 \mathrm{sec}$ prepulse to $-95 \mathrm{mV}$ (open triangles) and after $25 \mathrm{sec}$ prepulse to $-95 \mathrm{mV}$. Line, open circles, Current after prepulse to $-60 \mathrm{mV}$. In the cell of $C$, no Kv1.4 mRNA was detected as shown in the inset. In contrast, in the cell of $D, \mathrm{Kv} 1.4 \mathrm{mRNA}$ was detected after recording as shown in the inset. Note that there is almost no difference between the cells in $C$ and $D$ in recovery kinetics.

Rettig et al., 1994). In contrast, A currents in cholinergic interneurons recovered rapidly with inactivation time constants of near 20 and $300 \mathrm{msec}$. So, despite the similarity in voltage dependence and kinetics of inactivation development, homomeric Kv1.4 channels are unlikely to be significant contributors. Kv1.1, Kv1.2, and Kv1.4 channels with $\beta 1$ subunits can also be discarded on the same grounds, as well as their more rapid inactivation development (Rettig et al., 1994; Heinemann et al., 1996).

If channels composed of Kv1 family subunits do not underlie the A current, then do channels containing Kv4.2 and Kv4.1 subunits? The pharmacological properties of the Kv4.2 and Kv4.1 channels are very similar to interneuronal A-type channels. In heterologous expression systems, Kv4.2 and Kv4.1 channels are potently blocked by 4-AP, with $\mathrm{IC}_{50}$ values in the low millimolar range (Baldwin et al., 1991; Chabala et al., 1993; Serodio et al., 1994, 1996). Moreover, homomeric Kv4.2 channels exhibit a timeand voltage-dependent block by 4-AP that is virtually identical to that seen in interneurons (Tseng et al., 1996; Fiset et al., 1997). Kv4.2 channels are also relatively insensitive to TEA, as were the A-type channels in interneurons. $\mathrm{Cd}^{2+}$ also dramatically shifts the voltage dependence of Kv4.2 channels toward more depolarized potentials (Fiset et al., 1997), possibly reflecting the presence of cysteine residues within a region of the pore involved in gating (Yellen et al., 1994). However, the voltage dependence of activation and inactivation of Kv4 channels expressed in Xenopus oocytes is considerably more depolarized than the currents seen here (Baldwin et al., 1991; Serodio et al., 1994, 1996). Furthermore, the development and recovery from inactivation is slower. However, when a brain-derived 2-4 kb cRNA fraction is coinjected with Kv4.2 subunit cRNA, the resulting channels give rise to currents that are very similar in voltage dependence and kinetics to the A currents in interneurons (Chabala et al., 1993; Serodio et al., 1994).

The inference that Kv4.2 subunits are major constituents of $\mathrm{K}^{+}$ channels in the proximal somatodendritic membrane of cholinergic interneurons and that Kv1.4 subunits are not is in agreement with immunocytochemical studies of the subcellular localization of these subunits shown here and in studies in other cell types (Sheng et al., 1992, 1993; Alonso and Widmer, 1997) (cf. MaleticSavatic et al., 1995). Like previous studies, we found evidence for 

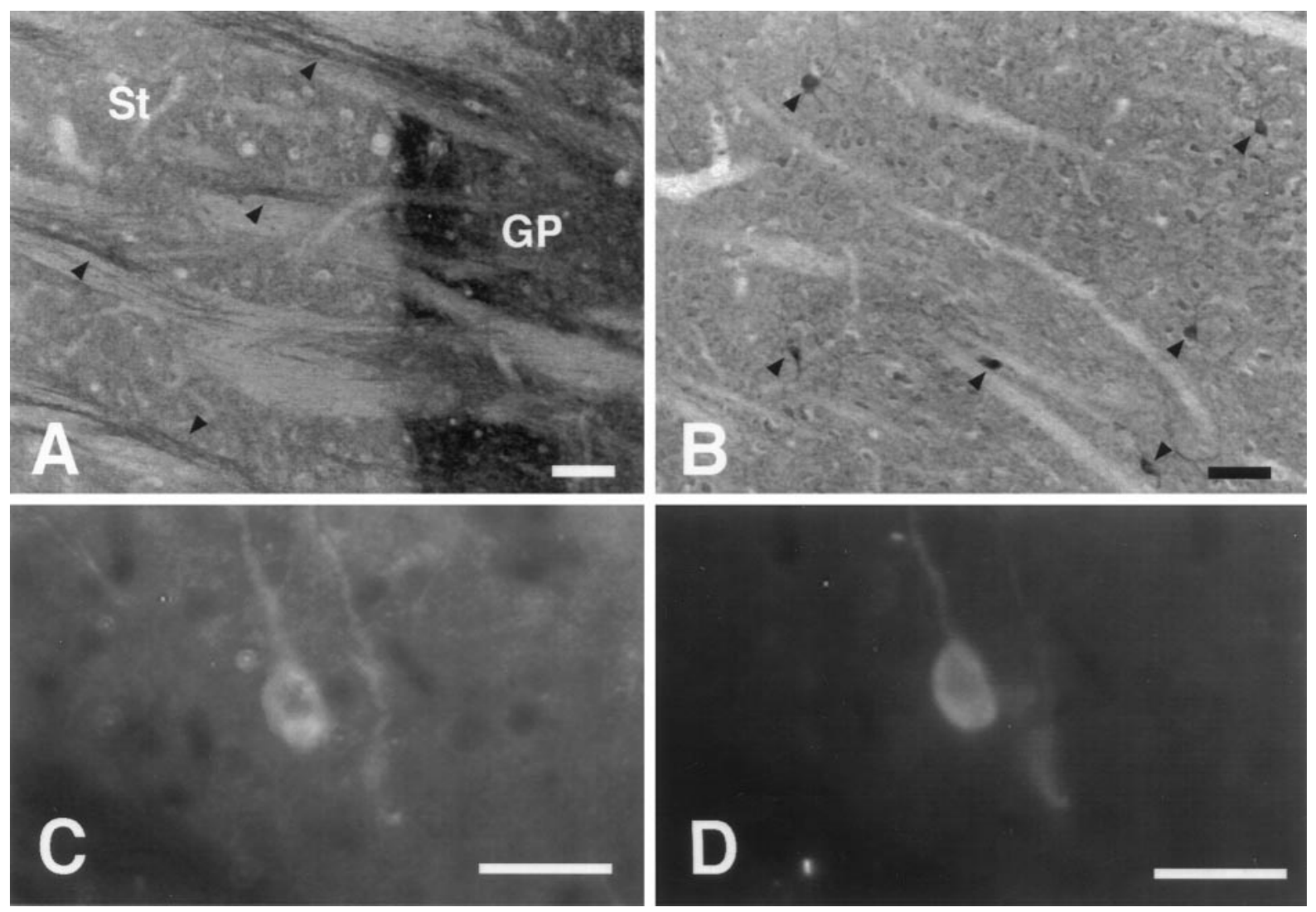

Figure 10. The somatodendritic membrane of cholinergic interneurons possesses Kv4.2 but not Kv1.4 immunoreactivity. $A$, Immunohistochemical localization of Kv1.4 in the striatum. Kv1.4-immunoreactive fiber bundles (arrowheads) course through the striatum to the globus pallidus (GP). Neuronal somata within the striatum show no immunoreactivity to Kv1.4. Note a dense Kv1.4 staining in the GP. B, Immunohistochemical localization of Kv4.2C in the striatum. Medium to large somata (arrowheads) were densely labeled with Kv4.2C, whereas small cells were weakly labeled. Note that proximal dendrites of medium to large cells were also labeled. $C$, $D$, Examples of striatal neurons double-labeled for $\mathrm{Kv} 4.2 \mathrm{C}(C)$ and $C h A T(D)$. $C$, Two neurons labeled for Kv4.2C with FITC. $D$, the same two neurons were labeled for ChAT and visualized with Texas Red. Scale bars: $A, 50 \mu \mathrm{m} ; B, 100 \mu \mathrm{m} ; C$, $D, 50 \mu \mathrm{m}$.

Kv4.2 subunits in the somatodendritic membrane of cholinergic interneurons and medium spiny neurons, whereas Kv1.4 subunits were restricted to axons and terminals. A similar subcellular distribution has been inferred for sympathetic ganglion neurons based on RNase protection and physiological assays (Dixon and McKinnon, 1996). Although the immunocytochemical and molecular evidence presented makes a strong case, this evidence is correlative. Unequivocal proof that somatodendritic A-type $\mathrm{K}^{+}$ channels are dominated by Kv4.2 and Kv4.1 subunits will come only from a more direct demonstration, such as that afforded by antisense knockdowns of Kv4.2 mRNA.

\section{The properties of A-type channels are consistent with a role in allowing slow repetitive discharge}

One of the first cellular functions attributed to A-type currents was the slowing of interspike depolarization (Connor and Stevens, 1971b). This slowing enabled neurons to discharge at very slow rates, a capacity that was absent in early Hodgkin-Huxley models based on axonal currents. To accomplish this goal, the A-type conductance needs to open at subthreshold membrane potentials and then inactivate, allowing spike threshold to be reached. On repolarization of the spike, channels must reprime or deinactivate quickly, so that the ensuing depolarization is capable of opening them once again. These three features, subthreshold activation, rapid inactivation, and rapid recovery from inactivation, were all features of the A current in cholinergic interneurons. They are also characteristics of Kv4.2 and Kv4.1 channels when combined with an ancillary protein (Serodio et al., 1994, 1996).

Another feature of these channels that is of potential functional importance was their sensitivity to $\mathrm{Cd}^{2+}$. The dramatic effects of $\mathrm{Cd}^{2+}$ on the voltage dependence and kinetics of A-channel gating suggest that these channels may be allosterically regulated by other divalent cations. $\mathrm{Zn}^{2+}$ is a particularly intriguing candidate in this regard. Histochemical studies have shown a high levels of vesicular $\mathrm{Zn}^{2+}$ in the striatum (Vincent and Semba, 1989; Mengual et al., 1995). The distribution of $\mathrm{Zn}^{2+}$ is not uniform and is often associated with striosomal compartments, particularly in the rostral striatum. If the vesicular $\mathrm{Zn}^{2+}$ is coreleased from glutamatergic terminals as it is in other regions (Assaf and Chung, 1984), corticostriatal activity could allosterically modulate the voltage dependence of interneuronal A-type channels. In agreement with previous work (Huang et al., 1993; Erdelyi, 1994; Spires and Begenisich, 1994), preliminary studies have shown that $\mathrm{Zn}^{2+}(100 \mu \mathrm{M})$ does shift the voltage dependence of A current channel gating, although not as potently as $\mathrm{Cd}^{2+}$. This modulation should disenable slow, repetitive activity and promote higher-frequency, less-regular discharge. 


\section{REFERENCES}

Agus ZS, Dukes ID, Morad M (1991) Divalent cations modulate the transient outward current in rat ventricular myocytes. Am J Physiol 261:C310-C318.

Alonso G, Widmer H (1997) Clustering of KV4.2 potassium channels in postsynaptic membrane of rat supraoptic neurons: an ultrastructural study. Neuroscience 77:617-621.

Andreasen M, Hablitz JJ (1992) Kinetic properties of a transient outward current in rat neocortical neurons. J Neurophysiol 68:1133-1142.

Aosaki T, Tsubokawa H, Ishida A, Watanabe K, Graybiel AM, Kimura M (1994) Responses of tonically active neurons in the primate's striatum undergo systematic changes during behavioral sensorimotor conditioning. J Neurosci 14:3969-3984.

Assaf SY, Chung SH (1984) Release of endogenous $\mathrm{Zn}^{2+}$ from brain tissue during activity. Nature 308:734-736.

Baldwin TJ, Tsaur ML, Lopez GA, Jan YN, Jan LY (1991) Characterization of a mammalian cDNA for an inactivating voltage-sensitive $\mathrm{K}^{+}$ channel. Neuron 7:471-483.

Bargas J, Howe A, Eberwine J, Cao Y, Surmeier DJ (1994) Cellular and molecular characterization of $\mathrm{Ca}^{2+}$ currents in acutely isolated, adult rat neostriatal neurons. J Neurosci 14:6667-6686.

Baro DJ, Levini RM, Kim MT, Willms AR, Lanning CC, Rodriguez HE, Harris-Warrick RM (1997) Quantitative single-cell-reverse transcription-PCR demonstrates that A-current magnitude varies as a linear function of shal gene expression in identified stomatogastric neurons. J Neurosci 17:6597-6610.

Bertoli A, Moran O, Conti F (1994) Activation and deactivation properties of rat brain $\mathrm{K}^{+}$channels of the Shaker-related subfamily. Eur Biophys J 23:379-384.

Bertoli A, Moran O, Conti F (1996) Accumulation of long-lasting inactivation in rat brain $\mathrm{K}(+)$-channels. Exp Brain Res 110:401-412.

Chabala LD, Bakry N, Covarrubias M (1993) Low molecular weight poly(A) ${ }^{+}$mRNA species encode factors that modulate gating of a non-Shaker A-type $\mathrm{K}^{+}$channel. J Gen Physiol 102:713-728.

Cimino GD, Metchette K, Isaacs ST, Zhu YS (1990) More false positive problems. Nature 345:773-774.

Connor JA, Stevens CF (1971a) Voltage clamp studies of a transient outward membrane current in gastropod neural somata. J Physiol (Lond) 213:21-30.

Connor JA, Stevens CF (1971b) Prediction of repetitive firing behaviour from voltage clamp data on an isolated neurone soma. J Physiol (Lond) 213:31-53.

Covarrubias M, Wei AA, Salkoff L (1991) Shaker, Shal, Shab, and Shaw express independent $\mathrm{K}^{+}$current systems. Neuron 7:763-773.

Deal KK, England SK, Tamkun MM (1996) Molecular physiology of cardiac potassium channels. Physiol Rev 76:49-67.

Dixon JE, McKinnon D (1996) Potassium channel mRNA expression in prevertebral and paravertebral sympathetic neurons. Eur J Neurosci 8:183-191.

Erdelyi L (1994) Zinc modulates A-type potassium currents and neuronal excitability in snail neurons. Cell Mol Neurobiol 14:689-700.

Fiset C, Clark RB, Shimoni Y, Giles WR (1997) Shal-type channels contribute to the $\mathrm{Ca}^{2+}$-independent transient outward $\mathrm{K}^{+}$current in rat ventricle. J Physiol (Lond) 500:51-64.

Foehring RC, Surmeier DJ (1993) Voltage-gated potassium currents in acutely dissociated rat cortical neurons. J Neurophysiol 70:51-63.

Graybiel AM (1990) Neurotransmitters and neuromodulators in the basal ganglia. Trends Neurosci 13:244-254.

Graybiel AM, Aosaki T, Flaherty AW, Kimura M (1994) The basal ganglia and adaptive motor control. Science 265:1826-1831.

Gurantz D, Ribera AB, Spitzer NC (1996) Temporal regulation of Shaker- and Shab-like potassium channel gene expression in single embryonic spinal neurons during $\mathrm{K}^{+}$current development. J Neurosci 16:3287-3295.

Gustafsson B, Galvan M, Grafe P, Wigstrom H (1982) A transient outward current in a mammalian central neurone blocked by 4-aminopyridine. Nature 299:252-254.

Hagiwara S, Yoshida S, Yoshii M (1981) Transient and delayed potassium currents in the egg cell membrane of the coelenterate, Renilla koellikeri. J Physiol (Lond) 318:123-141.

Hamill OP, Marty A, Neher E, Sakmann B, Sigworth FJ (1981) Improved patch-clamp techniques for high resolution current recording from cells and cell-free membrane patches. Pflügers Arch 391:85-100. Heinemann SH, Rettig J, Graack HR, Pongs O (1996) Functional char- acterization of $\mathrm{Kv}$ channel beta-subunits from rat brain. J Physiol (Lond) 493:625-633.

Hille B (1992) Ionic channels of excitable membranes. Sunderland, MA: Sinauer.

Hornykiewcz O (1973) Dopamine in the basal ganglia. Its role and therapeutic implications. Br Med Bull 29:172-178.

Huang RC, Peng YW, Yau KW (1993) Zinc modulation of a transient potassium current and histochemical localization of the metal in neurons of the suprachiasmatic nucleus. Proc Natl Acad Sci USA 90:11806-11810.

Huguenard JR, McCormick DA (1992) Simulation of the currents involved in rhythmic oscillations in thalamic relay neurons. J Neurophysiol 68:1373-83.

Huguenard JR, Coulter DA, Prince DA (1991) A fast transient potassium current in thalamic relay neurons: kinetics of activation and inactivation. J Neurophysiol 66:1304-1315.

Kawaguchi Y (1992) Large aspiny cells in the matrix of the rat neostriatum in vitro: physiological identification, relation to the compartments and excitatory postsynaptic currents. J Neurophysiol 67:1669-1682.

Kawaguchi Y (1993) Physiological, morphological, and histochemical characterization of three classes of interneurons in rat neostriatum. J Neurosci 13:4908-4923.

Kemp JM, Powell TP (1971) The synaptic organization of the caudate nucleus. Philos Trans R Soc Lond B Biol Sci 262:403-412.

Klee R, Ficker E, Heinemann U (1995) Comparison of voltagedependent potassium currents in rat pyramidal neurons acutely isolated from hippocampal regions CA1 and CA3. J Neurophysiol 74:1982-1995.

Maletic-Savatic M, Lenn NJ, Trimmer JS (1995) Differential spatiotemporal expression of $\mathrm{K}^{+}$channel polypeptides in rat hippocampal neurons developing in situ and in vitro. J Neurosci 15:3840-3851.

Mayer ML, Sugiyama K (1988) A modulatory action of divalent cations on transient outward current in cultured rat sensory neurones. J Physiol (Lond) 396:417-433.

McCormack K, Lin JW, Iverson LE, Rudy B (1990) Shaker K ${ }^{+}$channel subunits from heteromultimeric channels with novel functional properties. Biochem Biophys Res Commun 171:1361-1371.

Mengual E, Casanovas-Aguilar C, Perez-Clausell J, Gimenez-Amaya JM (1995) Heterogeneous and compartmental distribution of zinc in the striatum and globus pallidus of the rat. Neuroscience 66:523-537.

Monyer H, Lambolez B (1995) Molecular biology and physiology at the single-cell level. Curr Opin Neurobiol 5:382-387.

Neher E (1971) Two fast transient current components during voltage clamp on snail neurons. J Gen Physiol 58:36-53.

Nisenbaum ES, Wilson CJ, Foehring RC, Surmeier DJ (1996) Isolation and characterization of a persistent potassium current in neostriatal neurons. J Neurophysiol 76:1180-1194.

Phelps PE, Houser CR, Vaughn JE (1985) Immunocytochemical localization of choline acetyltransferase within the rat neostriatum: a correlated light and electron microscopic study of cholinergic neurons and synapses. J Comp Neurol 238:286-307.

Pongs O (1993) Structure-function studies on the pore of potassium channels. J Membr Biol 136:1-8.

Rettig J, Heinemann SH, Wunder F, Lorra C, Parcej DN, Dolly JO, Pongs O (1994) Inactivation properties of voltage-gated $\mathrm{K}^{+}$channels altered by presence of beta-subunit. Nature 369:289-294.

Rogawski MA (1985) The A current: how ubiquitous a feature of excitable cells is it? Trends Neurosci 8:214-219.

Rudy B (1988) Diversity and ubiquity of K channels. Neuroscience 25:729-749.

Schroter KH, Ruppersberg JP, Wunder F, Rettig J, Stocker M, Pongs O (1991) Cloning and functional expression of a TEA-sensitive A-type potassium channel from rat brain. FEBS Lett 278:211-216.

Serodio P, Kentros C, Rudy B (1994) Identification of molecular components of A-type channels activating at subthreshold potentials. J Neurophysiol 72:1516-1529.

Serodio P, Vega-Saenz de Miera E, Rudy B (1996) Cloning of a novel component of A-type $\mathrm{K}^{+}$channels operating at subthreshold potentials with unique expression in heart and brain. J Neurophysiol 75: 2174-2179.

Sewing S, Roeper J, Pongs O (1996) Kv beta 1 subunit binding specific for shaker-related potassium channel alpha subunits. Neuron 16:455-463.

Sheng M, Tsaur ML, Jan YN, Jan LY (1992) Subcellular segregation of two A-type $\mathrm{K}^{+}$channel proteins in rat central neurons. Neuron 9:271-284. 
Sheng M, Liao YJ, Jan YN, Jan LY (1993) Presynaptic A-current based on heteromultimeric $\mathrm{K}^{+}$channels detected in vivo. Nature 365:72-75.

Song W-J, Surmeier DJ (1996) Voltage-dependent facilitation of calcium currents in rat neostriatal neurons. J Neurophysiol 76:2290-2306.

Spires S, Begenisich T (1994) Modulation of potassium channel gating by external divalent cations. J Gen Physiol 104:675-692.

Stefani A, Calabresi P, Mercuri NB, Bernardi G (1992) A-current in rat globus pallidus: a whole-cell voltage clamp study on acutely dissociated neurons. Neurosci Lett 144:4-8.

Stuhmer W, Ruppersberg JP, Schroter KH, Sakmann B, Stocker M, Giese KP, Perschke A, Baumann A, Pongs O (1989) Molecular basis of functional diversity of voltage-gated potassium channels in mammalian brain. EMBO J 8:3235-3244.

Surmeier DJ, Bargas J, Kitai ST (1988) Voltage-clamp analysis of a transient potassium current in rat neostriatal neurons. Brain Res 473:187-192.

Surmeier DJ, Bargas J, Hemmings Jr HC, Nairn AC, Greengard P (1995) Modulation of calcium currents by a D1 dopaminergic protein kinase/ phosphatase cascade in rat neostriatal neurons. Neuron 14:385-397.

Surmeier DJ, Song W-J, Yan Z (1996) Coordinated expression of dopamine receptors in neostriatal medium spiny neurons. J Neurosci 16:6579-6591.

Thompson S (1982) Aminopyridine block of transient potassium current. J Gen Physiol 80:1-18.
Tseng GN, Jiang M, Yao JA (1996) Reverse use dependence of Kv4.2 blockade by 4-aminopyridine. J Pharmacol Exp Ther 279:865-876.

Tukey JW (1977) Exploratory data analysis. Menlo Park, CA: Addison-Wesley.

Vincent SR, Semba K (1989) A heavy metal marker of the developing striatal mosaic. Brain Res Dev Brain Res 45:155-159.

Wilson CJ, Chang HT, Kitai ST (1990) Firing patterns and synaptic potentials of identified giant aspiny interneurons in the rat neostriatum. J Neurosci 10:508-519.

Wu R-L, Barish ME (1992) Two pharmacologically and kinetically distinct transient potassium currents in cultured embryonic mouse hippocampal neurons. J Neurosci 12:2235-2246.

Yan Z, Surmeier DJ (1996) Muscarinic (m2/m4) receptors reduce Nand P-type $\mathrm{Ca}^{2+}$ currents in rat neostriatal cholinergic interneurons through a fast, membrane-delimited, G-protein pathway. J Neurosci $16: 2592-2604$.

Yan Z, Song W-J, Surmeier DJ (1997) D2 dopamine receptor reduce $\mathrm{N}$-type $\mathrm{Ca} 2+$ currents in rat neostriatal cholinergic interneurons though a membrane-delimited, protein kinase $\mathrm{C}$-insensitive pathway. J Neurophysiol 78:1003-1015.

Yellen G, Sodickson D, Chen TY, Jurman ME (1994) An engineered cysteine in the external mouth of a $\mathrm{K}^{+}$channel allows inactivation to be modulated by metal binding. Biophys J 66:1068-1075. 